DOI: https://doi.org/10.31874/2309-1606-2021-27-1-12 УДК 1(091)

\title{
Ігор Бурковський
}

\section{Апологія української кантіани: критика нігілістичної критики першої українськомовної «Критики»}

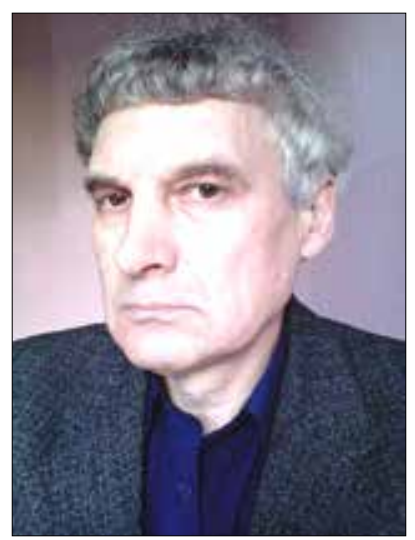

Стаття присвячена рецензії на український переклад «Критики чистого розуму» (КЧР), надрукованій у попередньому числі журналу. Публікація I. Іващенка та В. Терлецького являє собою спробу довести тезу про незадовільну якість перекладу - стаття доводить невдалість цієї спроби. Показано, що більшість зауваг рецензентів є неспроможними, $i$, що головніше, викладеного матеріалу вкрай недостатньо для доведення зазначеної тези. Фатально слабким місцем рецензії є методика оцінювання перекладу. Незадовільна якість тексту означає не просто наявність у ньому хиб, а високу їх частотність. У випадку розлогого тексту потрібна демонстрація на репрезентативній вибірці (запропоновано ії орієнтовний формат) - нічого подібного в рещензії немає. Хоч частина ї̈ зауваг - термінологічні, що може означати й помилки високої частотності - через повторюваність певних термінів, але насправді слушні моменти тих зауваг зводяться до виявлення кількох недоглядів, а також варіативності перекладу деяких менш важливих термінів - неусуненої здебільшого через брак часу. Рещензія стверджує, що терміни слід перекладати "скрізь однаково», а вжиття синоніма спричиняє, і то неминуче, «втрату думки автора й руйнування структури аргументації». Перше застосовне з обмеженнями, надто у випадку КЧР, яка не відзначається термінологічною скрупульозністю, а друге є великим перебільшенням. Рецензенти не продемонстрували жодного такого тяжкого наслідку синонімії термінів. Насправді рецензія доводить лише те, що в перекладі трапляються огріхи але це природно, вони є в будь-якому перекладі, в українському їх додатково зумовили несприятливі умови, в яких він робився. Для нейтралізації цих хиб потрібно розбудовувати й поширювати список поправок до тексту, які будуть ураховані в другому виданні.

Ключові слова: переклад, термінологія, доказовість, контраргументація, Імануель Кант, «Критика чистого розуму», філософська освіта.

(C) І. Бурковський, 2021 


\section{Вступ}

Позитивна рецензія може бути коротенькою й обмежуватися загальними фразами. Натомість рецензія негативна має бути достатньо аргументована, інакше можуть виникати певні підозри щодо мотивів її написання, як і сумніви в слушності оцінки. Чи можна визнати достатньо аргуметованою рецензію на український переклад «Критики чистого розуму» (далі по тексту - КЧР) Імануеля Канта, опубліковану у першому числі журналу «Філософія освіти» за 2020 рік [Іващенко, Терлецький 2020]? Відразу можна сказати: малоймовірно, щоб двох десятків спорадичних зауваг на пів тисячі сторінок тексту було достатньо для категоричного висновку про його непридатність - навіть якби всі ті зауваги до одної були слушними й істотними, що насправді (побачимо згодом) далеко не так.

Я не претендую на 100\% рації в суперечці. Безперечно, помилки в перекладі $\epsilon$ - переклади без помилок навряд чи бувають (хіба що дуже короткі). Чимало помилок $є$ в російських перекладах, що досі лишаються для багатьох українців чи не єдиним джерелом знайомства 3 творами Канта. Не бракує помилок і в тих філософських перекладах, що належать моїм нинішнім рецензентам. Зумовлені ті хиби, по-перше, вадами компетенції перекладача (і редактора, якщо він є) - яка не може бути ідеальною, абсолютною, по-друге, чинниками психологічного характеру - різні аберації, збої, плюс неуважність: такі недогляди в людей не рідкість (не виняток і сам Кант). Верстка з виправленнями таких хиб на кожній сторінці - звичайна річ у видавничій справі. Але далеко не всі помилки на цьому грунті усувають редактори й коректори. Вони часом не усувають (через ту ж таки неуважність) і найпростіших, очевидних - так, в обговорюваній рецензії бачимо: «особливості Кантову синтаксису», «як перекладають і видаються сьогодні твори класиків», «таке перекладацьке рішенні», «з помилковим пов'язання вказівного займенника» [Іващенко, Терлецький 2020: 213, 215, 219, 224]), часом і додають нові помилки. А коли ви в перекладі переплутали щось із чимось і так і не помітили цього, то тут зазвичай може допомогти (i то далеко не завжди) лише висококваліфікований редактор - а це в нас велика рідкість.

\section{Про критерії оцінювання якості перекладу}

Якість, за Геґелем (див. § 104-105 «Енциклопедії»), простежується в співвідношенні кількісних показників. Для нашого випадку, оцінки якості наукового перекладу в найважливішому аспекті - ступінь адекватності передання оригіналу - це співвідношення кількості помилок і обсягу тексту. Отож для негативної оцінки перекладу потрібно не просто виявити в ньому деяку кількість хиб, а констатувати високу їх частотність - чого в рецензії не бачимо. Щоправда, деякі її зауваги мають позірно множинний 
(чи навіть системний) характер, стосуючися перекладу певних важливих термінів, що може означати помилки не лише «особливої тяжкості», а й високочастотні, з огляду на повторюваність таких термінів, але я постараюся показати, що в тих заувагах небагато слушності.

Про яку саме частотність ідеться? Питання конкретної міри, визначення критичного порогу між «задовільно» і «незадовільно», $є$ радше дискусійним. Та в певних випадках висновок про те, що цю міру перевищено, може бути практично бездискусійним (нехай з ним і не погоджується творець критикованого тексту). Пригадується якийсь імпліцитно негативний відгук: серйозних хиб «більше, ніж сторінок» - як на мене, цілком достатнім для незадовільної оцінки є й нижчий показник, скажімо, серйозна хиба щодві сторінки. (За умовну сторінку можна рахувати традиційні 1800 знаків або, для більшої зручності, 2 тис., 1/20 а.а.).

У випадку незначного обсягу перекладу (кількадесят сторінок) зазвичай варто вимагати суцільної експертизи, для розлогіших здебільшого доводиться вдовольнятися вибірковою. Тут важливо зробити репрезентативну вибірку. Для незадовільної оцінки достатньо переконливою, гадаю, можна визнати демонстрацію на трьох симетрично розташованих уривках із різних частин основного тексту (початкової, серединної та прикінцевої) - сумарно щонайменше 10\% перекладу, загальним обсягом принаймні 1 а.а. (за очевидного надміру помилок, а зазвичай цей мінімум має становити, либонь, 1,5 а.а.), у кожному з яких слід указати бодай мінімальну неприйнятну кількість хиб. У випадку КЧР, на мій погляд, це означає завдання обстежити три масиви по 20 умовних сторінок - виявлення в кожному по 10 серйозних помилок було б достатньо для незадовільної оцінки.

Деякі зразки негативного оцінювання перекладів (не завжди з відповідним експліцитним формулюванням).

Рецензія Густава Шпета на російський переклад тієї ж таки КЧР у виконанні дилетанта Миколи Соколова - дещо рапсодична (висловлюючися Кантовою мовою), та попри те переконлива. Вбивчу характеристику «Якщо знайшовся хоч один читач, що уважно простудіював Канта за цим перекладом і щось зрозумів, то який же він далекий від Канта» [Шпетт 1904: 551] яскраво проілюстровано: на кільканадцятьох журнальних сторінках наведено щось із сотню помилок перекладача, здебільшого грубих, а то й просто абсурдних. Вони однозначно свідчать про його глибоку різноаспектну некомпетентність, і це вселяє довіру до запевнення: «Такий увесь переклад: суцільне спотворення. Варто прочитати уважно будь-яку сторінку, щоб переконатися в його непридатності» [Шпетт 1904: 563], тож у цьому випадку, радше особливому, можна, либонь, і не вимагати визначення «питомої ваги» помилок. 
Числовий показник знаходимо в характеристиці першого російського перекладу Геґелевої логіки. «Всего грубых ошибок в переводе Дебольского можно насчитать значительно больше тысячи» [Анонім 1937: Х] - тобто щось із півтори на сторінку. Цей відгук, одначе, викликає критику (А. Власов). Цілком можливо, що він відповідає дійсності, проте доказовим його визнати годі - наведено лише декілька прикладів. Звісно, про значну їх кількість не могло йтися, але слід було б зосередитися на уривку бодай із кількох сторінок підряд - відповідні дані («5 сторінок - 10 помилок») були б хоч і не цілком вистачальним, але вже досить вагомим доказом.

Дещо з власної практики. У післяслові до українського перекладу «Критики практичного розуму» сказано, що її російська версія (досі той самий Соколов, хоч і неодноразово правлений) «рясніє більш або менш серйозними вадами» [Бурковський 2004a: 182]. У тій-таки післямові та в примітках наведено 42 таких випадки (не рахуючи ще кільканадцятьох, обережно схарактеризованих як вельми сумнівні). Завдяки цьому зацитоване твердження не є голослівним, але цього недостатньо для належної оцінки перекладу (вона, одначе, не входила в моє завдання) - бо зауваги стосуються цілого тексту, а не сконцентровані на якихось його частинах. Згадаймо тепер обговорювану тут рецензію: удвічі менше зауваг - щодо втричі довшого тексту ${ }^{1}$, при тому, що вона якраз спеціально йому присвячена.

Експертний відгук на робочу версію перекладу Кантової третьої «Критики», виконаного одним із моїх теперішніх рецензентів [Бурковський, et al. 2018: 122-124]. 3 поданого ним зразка (частина «Вступу» до твору, 0,5 а.а.) через обмеженість наданої мені журнальної площі розглянуто менш як половину. Указано близько двох десятків різних хиб (i задекларовано наявність іще деяких) - що мало не дорівнює кількості тих претензій, які автор рецензованого перекладу, черговий раз помінявшися зі мною ролями, разом з колегою висуває до розлогішої в сто з лишком (!) разів КЧР-2000. Частина моїх зауваг стосується другорядних моментів - але те саме можна сказати й про їхні, що ж до відзначених серйозних помилок, то їх частотність у розглянутій частині перекладу сягає двох випадків на сторінку.

Стаття про переклади Гегелевої «Феноменології», повний і частковий (бл. 2/3 а.а. тексту оригіналу) [Бурковський 2021]. I в першому, і в другому (його виконав інший мій нинішній рецензент) відзначено поважну кількість помилок, здебільшого серйозних - підрахувати їх не-

\footnotetext{
${ }^{1}$ Обсяг «Критики практичного розуму» в оригіналі - 391 тис. знаків, а КЧР (друге видання разом $з$ передмовою до першого) - 1, 275 млн., в обговорюваному перекладі 2000 р. (далі КЧР-2000) - 1, 105 млн.: українська мова компактніша за німецьку.
} 
просто. Кількість зауваг - близько чотирьох десятків, у деяких зазначено: «дві помилки (не рахуючи граматичної)», «принаймні дві помилки (не рахуючи механічної)», але таких поміток мало - через брак місця, і не тільки. Тут, mutatis mutandis, пасують слова зі згадуваної вище характеристики: «Перевод Дебольского изобилует грубыми ошибками и нередко сводится к совершенно лишенному смысла механическому набору слов» [Анонім 1937: Х] - а в таких випадках визначати кількість помилок проблематично.

Але суть моєї контраргументації - не в «medice, cura te ipsum». Я дам відповідь на всі закиди рецензії зосібна й загалом (не замовчуючи їх слушних моментів). Та спочатку - історичний екскурс: без нього неможливе належне уявлення про обговорювану книгу й саму цю дискусію.

\section{3 історії українського перекладу КЧР}

У рецензії (досить позитивній) на мій переклад другої «Критики» Віталій Терлецький стверджує: цей переклад кращий за перший, а як причину цього відзначив у мене «зміну ставлення до текстів німецького філософа» [Терлецький 2006: 135]. Процитовані слова, цілком неслушні, створюють враження, ніби я мав змогу працювати над тими текстами стільки, скільки вважав за потрібне. Насправді ж переклади робилися в жорстких рамках відомого видавничого проєкту, а перший - іще й в особливих обставинах.

Наприкінці минулого тисячоліття мене, як людину з філософською та лінгвістичною освітою (а до того ж і з певним досвідом редагування, зокрема перекладів), тодішнє видавництво «Юніверс» запросило на роль редактора перекладу КЧР. Я погодився, гадаючи, що робитиме його особа більш-менш компетентна. Що́ мене насправді чекало - про це дають уявлення слова вже спочилого перекладача, Анатолія Онишка: «Людина не може бути фахівцем у всьому. Я, наприклад, фахівець із буріння, 3 нафтовидобутку і хімічного обладнання, трохи з хімічної технології. А доводиться бути фахівцем і в соціології, і в філософії... Я брався навіть за Канта, російською книга називається “Критика чистого разума”. Я переклав дещо інакше - “Критика здорового глузду”» [Савчин 2008: 209].

Уже звідси видно, що то міг бути шедевр навіть шедевральніший, ніж у Соколова з його антимоніями замість антиномій (той хоч духовну семінарію закінчив, та й принципові «антибуквалізму» не поклонявся). Але сталася несподіванка. Минув досить чималий час, відколи робота нібито почалася, аж тут мене повідомили: перекладач відмовився від неї. Сам він розповідав так: «Сторінок 300 переклав, а потім облишив через непорозуміння з видавництвом» [Савчин 2008: 209]. Проєкт, фінансований зарубіжними грошедавцями, що ставили жорсткі терміни, а відтак і 
репутація видавництва опинилися під загрозою. Видавництво вирішило вийти зі скрути, розділивши текст навпіл і віддавши його двом перекладачам. Строку їм давано п'ять місяців (символічний збіг - скажуть знавці Канта), потім іще якийсь час відводився на доопрацювання перекладу. Перекладати першу частину (і потім допасовувати до неї другу) просили мене - я врешті погодився, розуміючи значення цієї справи. Щось блискуче за такий час зробити нереально, але задовільний текст, у межах пристойності - це можливо. Яким чином? Спосіб тут, либонь, один: не маючи часу на довгі розмірковування та дошукування - покластися на тих, хто раніше пройшов цей шлях. Усі притомні перекладачі використовують доступні їм тексти своїх попередників - а в моєму становищі значення їх було надзвичайним. Моя однокурсниця, кандидат філософських наук Тетяна Метельова, знайшла їх для мене три, з бібліотеки Інституту філософії та своєї власної: російський переклад Миколи Лоського у двох версіях (автентичнй, 1915 р., перевиданій 1993 стотисячним накладом, і 3 восьмитомника 1994) та болгарський Цеко Торбова (я тоді мав лише свій студентський конспект іншої російської версії). Переклад Лоського і став моїм головним дороговказом (професор Торбов, хоч і використовував чимало перекладів іншими мовами, теж ішов переважно за Лоським - на думку мимоволі спадає традиційне болгарське москвофільство). Довірявся я йому не сліпо. Виправив деякі його помилки, непомічені пізнішими редакторами, хоча принаймні одну помічену ними пропустив, а деякі мої відступи від його тексту виявилися й неслушними.

Уже наприкінці роботи (доопрацювання тексту) я дістав від членів Кантівського товариства - прикро, що видавництво пізно сконтактувало мене з ним - ще два переклади: від професора Анатолія Лоя польський (Романа Інгардена), а Михайло Мінаков добув мені з Інтернету англійський (Нормана Кемп Сміта). Це, на жаль, була вже радше «гірчиця по обіді», але в кількох випадках вони мені таки допомогли.

Коли ж зробив свою частку, мав новий сюрприз: доведеться робити ще й другу. Текст мого напарника виявився перекладом не з оригіналу, а з добре знайомого мені російського перекладу... Директор видавництва зміг домовитися зі спонсорами про три додаткові місяці. Час на доопрацювання лишався зовсім куций.

Так я став одноосібним перекладачем першої «Критики». Чи хтось допомагав? Були деякі поради від членів Кантівського товариства - можу згадати Анатолія Лоя, Євгена Причепія, а насамперед Віталія Терлецького, який був науковим експертом перекладу, санкціонував його публікацію. Наукового редактора для мене тоді не знайшлося. Був, щоправда, літературний - і він енергійно «виправляв»: інтелігенція на еліта (хто має уявлення про предмет, той оцінить), визначення на означення, видимість на видиво, необхідний на обов'язковий... Тобто хоча те, що Кант слідом за вольфіанцями та 
Крузієм допускав підміну деонтичної модальності алетичною - але не навпаки, і всякі такі речі для цього редактора були глибокою таємницею, але він своє діло знав: машинопис має бути помальований.

$€$ ще один специфічний тип помилок - ті, що внесені редакторами, коректорами, верстальниками. I в моєму випадку деякі з тих ляпів через відповідну організацію видавничого процесу потрапили в друк. («Скориговано» й ім'я Канта - див.: [Бурковський 2004: 374]. Або ще: я зберіг коректурний відбиток сторінки з приміткою 4 - там надруковано ро́зсудок, а в книзі стоїть розсудок: це лише один з подібних незрозумілих випадків). Їхня дія почала проявлятися вже на стадії експертного оцінювання. Текст для подання видавництво готувало без мого відома. Експерт Віталій Терлецький у відгуку написав: «Переклад, наскільки видається, ще не зазнав редакторської руки» (цитую за збереженим у мене примірником). У томуто й річ, що зазнав: видавцям залежало, щоб текст на оцінювання потрапив у якомога ліпшому вигляді, тож вони дали його тому редакторові він, у їх уявленні, мав його поліпшити. Його сміливі втручання породили низку недоладностей - експерт відніс їх на карб перекладача.

Згодом я зустрівся з Віталієм Терлецьким на засіданні Кантівського товариства, присвяченому обговоренню перекладу. Спілкування було небезхмарним. Пам'ятаю, він емоційно наполягав, що в таблиці категорій Einheit слід передати як $\epsilon$ ність (я, здається, не виклав як слід свого погляду). Ще він звернув мою увагу, що я маю зробити реєстри імен та понять. Я відповів, що час, відпущений мені для роботи, дуже обмежений, і ту дещицю, яка ще лишається, я можу використати лише на найважливіше - доопрацювання тексту (та ще деякі обов'язкові речі). Моєму візаві це навряд чи сподобалося - як згодом і те, що я не врахував деяких його зауваг з експертного відгуку - чи то не погодившися 3 ними, чи то через цейтнот. І це - в контексті того хибного враження, яке вселяв згаданий фрагмент перекладу, спотворений некомпетентним стороннім втручанням.

Ті епізоди пригадалися мені, коли я знайомився з його рецензією на свіжовиданий переклад. На ній варто зупинитися докладніше.

\section{Про одну давнішу рецензію на український переклад КЧР}

Перші абзаци - вступного характеру, далі ж іде ось що.

«Найперше про науковість видання «Критики чистого розуму». Здається, саме брак наукового підходу і $є$ основною вадою цього видання.

1. Оригінальне видання, з якого зроблений переклад, зазначено на звороті титулу. Однак без вказівки на видавця тексту книги - фактично дослідника, котрий здійснив певні кон'єктури, розставив розділові знаки і т. ін. (...) 
2. ...що переклад зроблено з другого видання, ми не зможемо дізнатися ані з титулу, ні з приміток. Це зазначено лише у передмові професора А. Лоя.

3. Будь-яке наукове видання, окрім тексту перекладу, містить ще й науковий апарат - предметний та іменний покажчики. Прикро, що в українському виданні такий апарат відсутній.

Брак наукового підходу помітний і в перекладі. Так, на с. 51, де йдеться про визначення Кантом трансцендентального пізнання, спостерігаємо відсутність у тексті перекладу прислівника «взагалі» (überhaupt) перед дієсловом «займатися», що істотно впливає на зміст. Там же маємо неточний переклад другої частини підрядного речення: у Канта йдеться про те, що «можливими a priori мають бути» не предмети, як перекладено, а «спосіб пізнання предметів»... Так само в таблиці категорій (с. 92) в групі категорій «кількості» в українському перекладі маємо «одиничність» (у Канта - Einheit), замість «єдність», що було б науково точніше» [Терлецький 2000: 6].

Звинувачення в «ненауковості» кидає тінь на переклад, але що за аргументи наведено? Перший - не відповідає дійсності: видавця тексту, котрий здійснив певні кон'єктури й т. ін., чорним по білому вказано на звороті титулу: «Hrsg. (тобто Herausgeber, видавець - I. Б.) Timmermann, Jens». Віталій Терлецький, можливо, ще не знав цього науковця (1970 p. н.), який уже тоді спромігся стати в один ряд з авторитетними кантознавцями, здійснивши нову редакцію твору (1998р.), що замінила в науковому обігу попередню, Раймунда Шмідта - в обох, до речі, теж $\epsilon$ помилки (див.: [McLaughlin 1999: 358]). Другий аргумент дивує: якщо інформацію подано в одному місці, то навіщо їі дублювати? У третьому викликає заперечення термін «науковий апарат», а ще більше - те, що зміст відповідного поняття рецензент обмежив до «предметний та іменний покажчики». 3 енциклопедичної статті «Апарат книги» [Ковальчук 2001: 609] довідуємося, що розрізняють довідково-допоміжний апарат, призначений для створення зручних умов для користування книгою, і науково-довідковий апарат - для кращого розуміння змісту. Предметний та іменний покажчики належать якраз до першого - поруч зі змістом, колонтитулами, анотацією - вони в книзі є, як і певні компоненти науково-довідкового апарату: вступна стаття, примітки, словничок латинських слів та виразів ${ }^{1}$. Відсутність тих покажчиків не $є$ ознакою «ненауковості» - якоїсь обліґаторної норми тут не існує, і далеко не кожне наукове видання їх має. Але корисності їх ніхто не заперечує, а

\footnotetext{
${ }^{1}$ Я запозичив його з московського «ювілейного» видання [Кант 1994: 705-710] - пересканував, розпізнав, а потім переклав перекладну частину комп'ютерною програмою. Через поспіх не помітив у російській версії доброго десятка помилок - тож вони перейшли й до української (їх указано в складеному пізніше короткому списку поправок до КЧР-2000).
} 
причину їх відсутності я пояснив персонально Віталієві Терлецькому на згадуваному засіданні Кантівського товариства в травні 2000 р.

Про докази недостатньо наукового підходу перекладача до роботи аж три наведені помилки.

1) Пропуск слова взагалі (überhaupt): заувага слушна - тим, що вказує на дійсний факт, але неслушна в твердженні, що це буцімто «істотно впливає на зміст». Як писав згодом сам Віталій Терлецький, у другому виданні (з якого зроблено переклад) «вагомий для дефініції першого видання прислівник «взагалі» хоч формально залишився на своєму місці, проте виявився логічно відірваним від свого суб’єкта... (...) Подеколи його навіть видаляють із тексту» [Терлецький 2018: XXXV] - як у виданнях К. Кербаха або Б. Ердмана, вочевидь вважаючи зайвим. Так і в Лоського (див. далі): цілком можливо, що й тут - свідоме вилучення. Подібних пропусків у нього чимало, і деякі з них я ненароком продублював (деякі й ненароком - бо я дотримуюсь іншої настанови). Російські читачі (і іже з ними, включно з нашими) багато десятиліть сприймали Кантів текст без цього слова (його не поновлено ні в редакції 1964 р. [Кант 1964: 121], ні в жодній з двох 1994 [Кант 1994: 56; Кант 1994а: 44] - щойно лише 2006 [Кант 2006: 79]), і практично нічого від того не втрачали.

2) Щодо вони мають бути можливими замість він має бути можливим. Це - єдина заувага, що відповідає критеріям слушності й серйозності. Цікаво, що це речення якесь підступне - на ньому спіткнувся не тільки я.

«Ich nenne alle Erkenntnis transzendental, die sich nicht so wohl mit Gegenständen, sondern mit unserer Erkenntnisart von Gegenständen, so fern diese a priori möglich sein soll, überhaupt beschäftigt» (B 25) [Kant 1998: 83].

У Лоського: «Я называю трансцендентальным всякое знание, занимающееся не столько предметами, сколько нашей способностью познания предметов, поскольку оно должно быть возможным а priori» [Кант 1999: 68] - крім згадуваного вже пропуску, ще принаймні дві помилки: 1) способностью познания (Erkenntnisart); 2) оно (diese). У редакції 1964 (так само - в обох виданнях 1994): «... всякое познание, занимающееся не столько предметами, сколько видами нашего познания предметов, поскольку это познание должно быть возможным a priori» [Кант 1964: 121; Кант 1994: 56; Кант 1994а: 44]: першу помилку замінено іншою, а другу - просто трансформовано, від чого вона не перестала бути помилкою. Я: «... усяке пізнання, що займається не стільки предметами, скільки нашим способом пізнання предметів, оскільки вони мають бути можливими а priori» [Кант 2000: 51] - одну помилку Лоського виправив, але другу, своєю чергою, ненароком замінив іншою помилкою, всупереч очевидному: soll - однина, а не множина. Російські редактори, намагаючися виправити Лоського, теж переплутали однину з множиною (в іменнику): мою неуважність стимулював стан авралу, а в тих фахівців вона 
видається дивною - тим більше, що цієї хиби від 1964 року незбагненним чином не помічають усе нові й нові кваліфіковані редактори. Вона збереглася й у російсько-німецькому виданні 2006 р., де тільки вставлено слово вообще, а в решті все залишено в недоторканості. А ось як цитує це речення та його фрагменти Віталій Терлецкий:

«Я називаю всяке пізнання трансцендентальним, яке взагалі займається не так предметами, як нашим способом пізнання, оскільки він повинен бути можливим а priori» [Терлецький 2005: XXIX]: теж пропуск, але значно серйозніший - сло́ва предметів.

Через кілька рядків: «нашим видом пізнання предметів» [Терлецький 2005: XXIX]: помилку виправлено, але допущено нову: видом замість способом.

Трохи далі: «взагалі займається <..> нашими (sic!) видом пізнання предметів...» [Терлецький 2005: XXXII] - і тут множина замість однини, крім помилкового видом.

У другому виданні книги:

Перше цитування - помилку збережено: «... займається взагалі не так предметами, як нашим способом пізнання, оскільки він повинен бути можливим a priori» [Терлецький 2018: XXXV].

Друге: «нашим способом пізнання» [Терлецький 2018: XXXVIII]: видом виправлено на способом, але натомість усунено слово предметів, тобто репродуковано помилку першого цитування.

Третє: помилкове видом виправлено, але неузгодженість у числі залишено - вийшло «.... нашими способом пізнання предметів....» [Терлецький 2018: XXXVIII]. Справді якесь зачароване місце (матеріал для психолінґвістів).

Та й це ще не все: формально правильна версія зі змістового погляду викликає певні сумніви. Р. Інґарден зауважує: «Не виключено, що це «diese» відноситься до самого пізнання і що а priori належить до «пізнання». У такому разі це місце слід було б тлумачити: “оскільки має бути можливим пізнання а priori” » [Kant 1986 I: 86]. Це не цілком збігається з версією Лоського, та в цьому світлі його друга помилка постає радше як просто сумнівне місце - але те саме стосується й інших перекладів. Я, одначе, не буду намагатися використати цю обставину для захисту своєї версії - результату недогляду.

3) “"Одиничність” замість “єдність”». Цей закид В. Терлецького, як я постараюся зараз довести, є цілком неслушним, помилковим. У курсі німецької класичної філософії вчать: кожен клас Кантових категорій має тріадичну структуру, тобто два контрарні поняття поєднуються в третьому - Кант це помітив, але висновків із цього не зробив. (Адекватні висновки означали б, можна сказати, катастрофічні наслідки для його системи). Так от, маємо тріаду категорій, і перша (точніше, її назва, термін) виявилася дискусійною. Щоб визначити, як має зватися ця 
перша категорія, слід звернутися до другої, щодо якої сто́рони дискусії згодні - множинності, і відповісти на питання: що́ є її протилежністю? Відповідь проста: одиничність. Можливі, щоправда, й інші терміноваріанти (вони з'являтимуться далі, виділені підкресленням), але основне значення відповідного слова має бути саме таке. Чи годиться на роль такого варіанта термін єдність? Звісно ж ні. Єдність - це одиничність, опосередкована множинністю, тобто цей термін за змістом годиться на роль варіанта третьої категорії, а не першої.

А з лінґвістичного погляду - чи можна німецьке Einheit (Кантових часів) перекладати як «одиничність» (чи якимось значеннєво тотожним словом)? Так, цілком (хоча в певних випадках - але не в цьому - воно перекладається і як «єдність»). Ось дані найавторитетніших джерел.

Словник братів Грім як перше значення Einheit вказує: «ноvós, die eins, einzahl, auch in der grammatik die einheit, numerus singularis ([гр.] ноvós, одиниця, однина - також у граматиці....)» [Grimm 1862: 198].

Словник Аделунга виділяє два основні (родові) значення слова. Перше - «Die Eigenschaft, da ein Ding Eins ist; ohne Plural, außer zuweilen von mehrern Arten» - цілком відповідає обговорюваній категорії. (Тут незмога розглядати видові значення, як «1) Die Eigenschaft, da ein Ding das einzige seiner Art ist...»). Не можна оминути й друге родове, з цікавими видовими: «2. Ein Ding selbst, welches Eins ist, so fern es Eins ist; mit dem Plural 1) in der Rechenkunst, ein Ding, aus dessen mehrmahligen Setzung eine Zahl entstehet... So besteht die Zahl sechs aus sechs Einheiten... 3) Ein untheilbares Ding, in der Methaphysik. So nannte Leibnitz die Monaden Einheiten der Natur» [Adelung 1811: 1708]: вони охоплюються нашим одиниця.

В обох словниках фігурує лат. unitas: брати Грім окреслююють ним значення слова в цілому, а Аделунг інформує, що Einheit утворене «від числівника ein, щоб виражати лат. unitas». Звернімося й до латинського прототипу. Беремо один з найсолідніших словників (відповідний том нашого словника Литвинова ще не з'явився) - за браком місця обмежимося першим поданим там значенням ūnitās: «The quality of being one in number» [Glare 2012: 2308].

А ось як передано категорію Einheit у кваліфікованому латинському перекладі Ф.Г. Борна: «Vnum (Vnitas)» [Kant 1796: 74] - поруч із очікуваним unitas знаходимо для себе додатковий терміноваріант Unum ( $\underline{\partial \mu \nu})$.

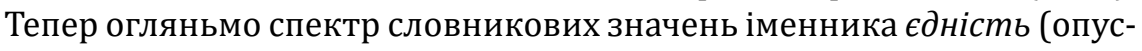
каю приклади):

«1. Тісний зв'язок, згуртованість, цілісність, неподільність. (...) 2 . Поєднання в одному цілому різних частин. (...) 3. Спільність чого-небудь, зосередженість чогось в одному місці і т. ін.» [Чумак... 2013: 697].

Крім другорядних значеннєвих відтінків «цілісність, неподільність» нічого, що вказувало б на придатність цього слова на таку роль. Можна, 
щоправда, згадати три єдності класицизму (місця, часу, дії) - але такі

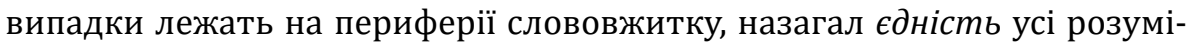
ють як «об'єднаність» і т. ін.

Підкреслю: я не вважаю одиничність найкращим варіантом (я не мав часу на пошуки такого) - мало того, він $є$ не дуже бажаним, бо одиничне традиційно виступає насамперед протилежністю загального. $Є$ ціла низка конкурентів: не лише названі вже одиниця, Одне, сумнівна з огляду на свою вузькоспецифічність однина, а й рідковживане одність (oneness) та дещо поширеніше $\epsilon \partial и н і с т ь$, але $\epsilon \partial н і с т ь$ тут пасує найменш, і особливо неслушним $є$ протиставлення її одиничності як буцімто правильного перекладу неправильному.

Помилковість варіанта Віталія Терлецького добре помітна в його перекладі «Пролегоменів» [Кант 2018: 48], де Кант чіткіш окреслює цей термін, подаючи поруч із ним у дужках, як частковий синонім, das Maß (міра). Це імплікує безальтернативний переклад: одиниця. Для КЧР можна вважати припустимим і якийсь інший - там такої цілковитої певності немає, бо Кант цього разу не дає вточнювального терміна.

3 усієї аргументації лишається тільки ОДНА серйозна заувага (плюс одна слушна, але не серйозна). Але рецензент своєї мети досягнув: публіка сприймає й запам'ятовує не аргументацію, а оцінку.

Відзначу, що невдовзі Віталій Терлецький відчутно змінив свою позицію щодо КЧР-2000, став трактувати їі цілком лояльно. В наступні роки він, наскільки мені відомо, не висловлювався про неї негативно (поза кількома закидами щодо деяких другорядних термінів), лише характеризує її як таку, що «інколи відрізняється від нашого перекладу» [Терлецький 2018: XIV], досить широко використовував у своїх публікаціях, ще й засудив ігнорування її [Терлецький 2015: 71].

Далі був мій згадуваний уже експертний відгук на переклад Віталія Терлецького [Бурковський, et al. 2018: 122-124]. Відгуки я завжди намагаюся давати об'єктивні й обгрунтовані - гадаю, що й цьому важко приписати протилежні риси.

\section{Відповіді на зауваження, висловлені у статті «Значливість перекладу для філософської освіти (на прикладі українського перекладу «Критики чистого розуму» Імануеля Канта)»}

\section{Преамбула}

А тепер - стаття, що за змістом являє собою рецензію на КЧР-2000, точніше, спробу довести твердження про нібито незадовільну якість перекладу, і складається, як пишуть автори, «з двох частин: термінологічної, де ми покажемо, чи дотримано в перекладі незмінність і тяглість 
Кантової термінології, і синтаксичної, де ми з'ясуємо, чи враховано термінологічні особливості Кантову (sic!) синтаксису» [Іващенко, \& Терлецький 2020: 213]. Жорсткі формулювання «чи враховано», «чи дотримано», надто щодо такого великого тексту, викликають подив (від науковців слід було б очікувати інформативних «наскільки враховано», «наскільки дотримано»), як і жорстка, «тотальна» відповідь на ті питання: «Після перевірки адекватності послідовності перекладу термінології та правильності тлумачення вкрай складного синтаксису, яким послуговувався Кант, ми дійшли до висновку, що Кантову аргументацію (всю? - І. Б.) зрозуміти неможливо, якщо читати лише наявний український переклад» [Іващенко, Терлецький 2020: 211]. Жодної інформації про ту перевірку, її методику, критерії оцінювання. Що винесений присуд страждає на брак доказовості, вже зауважено попередньо. Виникає питання: чи спирається він на якісь вагомі підстави, що їх автори дивним чином забули вказати, а чи є видаванням бажаного за дійсне?

Перш ніж переходити до зазначених підрозділів, приділимо увагу важливішим положенням незгаданої в процитованому описі вступної частини.

Про умови успішного перекладу - як твердять рецензенти, «усі ці умови не було належно дотримано (sic!)» [Іващенко, \& Терлецький 2020: 211-212]. Але вони наводять лише дві. Одна - це «домовленість професійної спільноти щодо того, як ми перекладаємо певні терміни певного автора, щоби під час обговорень не виникало термінологічної плутанини, коли на позначення того самого терміна ориґіналу використовують різні слова» [Іващенко, \& Терлецький 2020: 212], сюди ж «процес професійної комунікації перекладача з фаховою спільнотою» [Іващенко, \& Терлецький 2020: 213]. Така комунікація була, нехай і не вельми масштабна. Що ж до домовленості, то авторам має бути відомо, що це часто-густо річ дуже проблематична. На жаль, рамки статті не дозволяють мені розповісти про перипетії перекладу таких славнозвісних термінів, як Verstand чи Ding an sich - консенсусу щодо них досі немає. Та попри те якоїсь «плутанини» під час обговорень не помітно. Кожен уперто вживає (ще й із притиском) свою версію (жодні аргументи не пробивають страх визнати себе неправим) - але всі розуміють, про який термін оригіналу йдеться.

Але навряд чи відсутність такої домовленості має означати неуспішність перекладу. На мій погляд, терміновжиток у перекладах філософської класики якраз є потужним чинником впливу, що сприяє досягненню термінологічної одностайності в національному філософському дискурсі, тож треба дбати насамперед про узгодженість між перекладачами - готовність рухатися в цьому напрямку я демонстрував. 
Друга (й остання) умова: «Важлива також фігура перекладача... Передусім це має бути дослідник, який своїми публікаціями та дослідженнями довів свою обізнаність як із текстом, який перекладає, так і з традицією, до якої цей текст належить» [Іващенко, Терлецький 2020: 213]. Фігура перекладача, безперечно, вкрай важлива. Але критерій обрано не дуже вдалий. Згадаймо хоча б успішний переклад Романа Інгардена, що в його списку праць - лише одна стаття, дотична до Канта [Ingarden 1973], і то опублікована посмертно. Передовсім це має бути особа 3 належною компетенцією, а чи демонструвала вона раніше свою обізнаність із перекладаним текстом - не так важливо. Нагадаю також, що обізнаність, по-перше, завжди обмежена (надто коли йдеться про тисячі конкретних речень і слів), по-друге, не завжди тотожна розумінню - з цим не раз доводиться стикатися, розглядаючи тлумачення тих чи інших місць із Канта у фахових текстах (про це ще будемо говорити). Звісно, відповідна дослідницька спеціалізація перекладача - вагомий плюс, але такий порядок, за якого перекладати Шелінга мали б лише реномовані шелінгознавці (та ще й дивлячись якого Шелінга - раннього чи пізнього), Декарта - тільки авторитетні фахівці з картезіанства, Касірера - той, хто захистив дисертацію про нього і т. д. - відчутно затримав би розвиток філософського перекладу. Особливо нереальною ця вимога вузької спеціалізації бачиться в наших українських умовах, коли, як відзначають самі рецензенти, «більшість перекладів філософської класики, які маємо на сьогодні, зроблено не професійними філософами» [Іващенко, Терлецький 2020: 213] - тут прийнятна вже наявність у перекладача просто загальнофілософської підготовки. Зрештою, й сам Вiталій Терлецький не відмовляється перекладати авторів, обізнаність із якими не довів своїми публікаціями - як переконуємося з Google Scholar (де він постає насамперед і понад усе як перекладач: кантознавчі статті дають йому якихось три відсотки цитувань, левова частка припадає на переклади філософської літератури - але, як правило, чомусь не Канта). I потім: $€$ українські кантознавці, $є$ ціле Кантівське товариство, але ввесь дотеперішній здобуток їхньої громади на цій ниві - переклад (i то далеко не бездоганний, рецензію на нього я ще маю написати) однієї Кантової праці скромного обсягу, не рахуючи ще одного незавершеного наразі - про рівень його попередньої версії вже йшлося. Утім, така стриманість може бути й виправданою: рівень перекладацьких компетенцій наших кантознавців не видається надто високим - суджу ще й із того, як вони цитують Канта (перекладаючи самостійно). Погодьмося: за такого стану речей факт перекладу КЧР особою з-поза того кола не можна безоглядно засуджувати. Тим більше, що робити це випало гуманітарію, який не лише має загальнофілософську підготовку, а й довів (і продовжує доводити) свою обізнаність із традицією, започаткованою 
цим текстом - з німецькою класичною філософією - див., напр.: [Бурковський 1995]. Завдяки цьому перша українськомовна «Критика», попри умови її створення, стоїть на якісно вищому рівні за численні перекладні опуси тих осіб, що їх автори досить неслушно назвали «професійними філологами», з типовими для них яскравими проявами непрофесіоналізму (окремі приклади з одного такого див. у: [Бурковський 2021]). Її вади - це переважно недогляди та недоробки, мало пов'язані з філософською кваліфікацією перекладача.

Крім того, перекладач мав один додатковий козир - лінґвістичну підготовку (хоча теж, природно, обмежену, уже порівняно з нинішньою), у практичному й теоретичному аспектах - а це дуже важлива річ. Брак ї̈ призводить навіть кантознавця до грубих помилок у тлумаченні окремих місць тексту філософа (див.: [Бурковський, et al. 2018: 122-123]). Тут же те, що авторові цих рядків доводилося звертати увагу Віталія Терлецького ([Бурковський 2004b: 202; Бурковський, et al. 2018: 122]), що, як він сам тепер повторює, «Кантова німецька мова - це не сучасна німецька мова» [Іващенко, Терлецький 2020: 216]. Нарешті, відсутність цієї компетенції змовлює брак орієнтування при зверненні до лінгвістичних матерій: «... головним складно-підрядним реченням тут є: (...) Реченням-вставкою тут є...» [Іващенко, Терлецький 2020: 222). - Тут доводиться говорити не просто про цілком хибний синтаксичний аналіз, а про безсенсовне нефахове формулювання. Або - «Вкрай важливо правильно пов'язати суб'єкта головного речення 3 його займенниковим скороченням в підрядних» [Іващенко, Терлецький 2020: 212]: перелік і роз'яснення всіх недоладностей цього уривка (з урахуванням авторової інтенції) зайняли б у багато разів більше рядків, ніж він сам.

Звісно, прогалини в кантознавчій компетенції перекладача подекуди даються взнаки. Так, Володимир Єрмоленко колись звернув увагу: двічі не враховано відмінність Кантового Realität від Wirklichkeit (дійсність). Інший приклад: периферійний термін Vorstellungskraft передано як уява або здатність уявляти (неподолане вагання) - варіанти помилкові (див.: [Willaschek... 2015 3: 2575]), як і пропонований у рецензії, сила уявлення [Іващенко, Терлецький 2020: 220], цю помилку відзначу й у перекладі Віталія Терлецького [Кант 2018: 27, 81, 210] - зрештою, і в інших фахівців: їхня кантознавча компетенція теж лише відносна. Але такі вади не відбилися критично на рівні перекладу в цілому. Помилок цієї етіології (бодай імовірної) у ньому небагато - як можна судити й із претензій, висунутих рецензентами.

«Переклад термінів не можна змінювати й використовувати натомість синоніми, інакше неминучою є втрата думки автора й руйнування структури аргументації» [Іващенко, Терлецький 2020: 212). Це твердження значною мірою некоректне. $Є$ така річ, як термінологічні сино- 
німи - їх уживання загалом цілком правомірне. Так, «нім. Kausalität ми перекладаємо двояко, як каузальність або причиновість - із суто стилістичних міркувань, без жодної значеннєвої різниці» [Бурковський 2000: 488]. Це наслідує й Віталій Терлецький: «Ми без вагань долучилися до практикованого в українському перекладі «Критики чистого розуму» мововжитку: «причиновість» і «каузальність»» [Терлецький 2018: LIXLX]. Інші випадки двоякого передання одного терміна - коли перекладач спочатку вживав один варіант, потім знайшов кращий, але забув чи не встиг здійснити уніфікацію, чи коли він перекладає то так, то так - через вагання або ж недбальство, некомпетність. Тоді один з варіантів (часом і обидва) зазвичай являє неточність або помилку. Що ж до «втрати думки автора й руйнування структури аргументації», то далеко не кожна заміна перекладного терміна синонімом тягне за собою такий наслідок - він зазвичай пов'язаний з останнім із трьох зазначених типів («легітимна» варіантність; неточність; помилка). Окремо стоять випадки передання терміна (чи радше слова) то в один, то в інший спосіб, коли це зумовлено тим, що Кант уживає те слово в різних значеннях (не синонімічних), з них якесь може бути не термінологічне - такі випадки в КЧР аж ніяк не рідкість: кантознавці зауважують, що мова ориґіналу відзначається «вельми неусталеною лексикою й термінологією» [Жучков 1999: 8]. Отож настанова «перекладати терміни скрізь однаково», хоч і значною мірою слушна, застосовна з певними застереженнями, надто для цього твору.

Що «крім перекладу такі видання неодмінно мають містити ще багато чого» [Іващенко, Терлецький 2020: 214] - не погоджуся зі словом неодмінно. «Ідеться не про ідеал, а про норму, що віддавна стала звичною у фаховому середовищі провідних західних країн» [Іващенко, Терлецький 2020: 214] - насправді навіть у тих країнах не все так чудово, автор малює тут ідеалізовану картину. Скажімо, коментарі $є$ далеко не в усіх західних виданнях філософської класики - навіть академічного типу, не кажучи про інші (трапляються й такі, де немає навіть прізвища перекладача), не завжди є й предметний покажчик. А відсутність частини того спорядження в КЧР-2000 - радше вимушена.

«Професійний філософ, звісно, має читати тексти винятково мовою оригіналу» [Іващенко, Терлецький 2020: 212] - заперечу коротко: і в перекладах теж (наївним є уявлення, нібито переклад - тільки для тих, хто не знає мови оригіналу). Те, що рецензенти порушують цей свій припис фактом обговорення перекладу - це в певному сенсі добре, але український кантознавець має бути обізнаний зі всіма українськими перекладами Канта (байдуже, наскільки вони вдалі). Це потрібно й для рецензування одного з них - його можна краще зрозуміти при знайомстві з іншими. 
«В українському перекладі ніде не обгрунтовано й не пояснено, чому знехтувано перше видання «Критики»...» [Іващенко, Терлецький 2020: 213-214). Пояснення можна знайти в інших перекладах, напр.: «Брак часу не дозволив також зреалізувати задум дати переклад важливіших місць із першого видання...» [Бурковський 2004: 373]. Обгрунтую легітимність такого рішення: воно відповідає авторській волі Канта. Певні частини першого видання він забракував і не бажав більше їх оприлюднювати. Формат КЧР-2000 - друге видання плюс передмова до першого - це формат єдиного перекладу твору за життя автора [Kant 1796] - він, очевидно, проти нього не заперечував (хоча кантознавець Мирослав Желязний вважає, що «філософ, мабуть, “перевернувся б у могилі”, якби довідався, що сучасні польські студенти починають лектуру його твору з Передмови до видання A» [Żelazny 2013: 18]). Отож твердження, ніби ««Критику чистого розуму» українською мовою перекладено не повністю» [Іващенко, Терлецький 2020: 214] - дискусійне. Але, безперечно, ті забраковані частини теж мають бути доступні читачеві для кращого зрозуміння твору, простеження еволюції думки Канта - тільки подавати їх слід не паралельно з текстом другого (це не лише очевидне непошанування авторової волі, а й дезорієнтування читачів, як показує Желязний), а у вигляді додатка, що й буде зроблено згодом.

Тепер розглянемо претензії до окремих місць перекладу.

\section{Відповіді на зауваження 1-го підрозділу («Термінологія Канта»)}

Пункт 1-й [Іващенко, Терлецький 2020: 217] сюди віднесено безпідставно, бо про жодний термін там не йдеться. Але помилка - ззовні замість ізсередини - має місце, як кажуть французи. Ї̈̈ може достерегти й нефахівець - просто людина з середнім рівнем знання німецької мови. Це означає, що помилка - психологічного характеру. Трапляються в людей такі помилки - енантіосемічні. Я знаю не один цікавий приклад, але тут обмежуся близьким до нашої тематики: у виданнях Логіки Гегеля трапляється qualitative замість quantitative чи Negativen замість Positiven [Брушлинский 1937: 700, 707].

«Ця помилка, звісно, повністю змінює суть Кантової думки, що, здається, навіть не треба пояснювати» [Іващенко, Терлецький 2020: 217]. - Hi, пояснювати треба було. При спробі такого пояснення автор міг би побачити: обговорюваний недогляд істотно не змінює суті Кантової думки, бо локалізується не в ключовій її частині. Головний її зміст і пафос у тому, що душа споглядає себе не так, як вона є́, а так, як вона являється собі. Аргумент до цієї тези: душа споглядає себе відповідно до того способу, в який вона зазнає впливу (афекції), а звідки саме - це вже можна вважати другорядним порівняно з тими важливими положеннями. Тим більше, що Кант відзначав чималу подібність між зовнішнім і внутрішнім чуттями. 
Отож цю заувагу важко віднести до графи істотних - хоча й до неістотних теж. Уникаючи ускладненої класифікації, вживемо простого окреслення «слушна».

Пункт 2-й [Іващенко, Терлецький 2020: 217-218] зводиться ось до чого. У трьох місцях перекладу (інших таких випадків мені наразі невідомо - тоді як ці три вже були відомі) компонент Verstand- у складних словах переплутано з Vernunft-. Однак для звинувачення щодо «нерозрізнення в перекладі ключових термінів «die Vernunft» (розум) та «der Verstand» (розсуд)» [Іващенко, Терлецький 2020: 218] трьох помилок на 744 випадки вживання основи Verstand- за коректного, наскільки можу судити, передання Vernunft- у всіх 1213 випадках ${ }^{1}$ - вочевидь замало. Можна заперечити й проти твердження «головне перекладати ці терміни скрізь однаково»- тут відбилося надмірне захоплення рецензента відповідним підходом. Так, im transzendentalen Verstande (В 34) [Kant 1998: 94] цілком правомірно перекладено у трансцендентальному розумінні [Кант 2000: 57] (можна ще сенсі), a der gesunde Verstand (B 61) [Kant 1998: 117] як здоровий глузд [Кант 2000: 69] - так, зрештою, і у Віталія Терлецького [Кант 2018: 148].

Але зазначена триразова помилка - справді серйозна, і цього досить, щоб визнати заувагу слушною. У чому тут річ? Ту саму помилку знаходимо й у згаданого раніше ексголови Кантівського товариства: «...істинне пізнаємо в розумі» [Мінаков 2007: 10] (в академічному виданні, на яке зроблено посилання - «nur der Verstand erkennt das Wahre» (В 882) [Kant 1904: 551], так і в: [Kant 1998: 877]). Мене й пана Михайла, випускників філософського факультету (не трієчників), зі спеціальним зацікавленням німецькою класичною філософією, навряд чи можна підозрювати в незнанні такої елементарщини, як відмінність між Verstand i Vernunft. Тож причиною й тут - випадкові чинники. (У шановного кантознавця тут ще й неуважність у поданні номера сторінки - 882, що насправді відбиває пагінацію видання 1787 р. й стоїть поблизу номера, який слід було вказати - 551).

3. «Також вражає непослідовність перекладу центрального Кантового терміна «das/die Erkenntnis» та його множини «die Erkenntnisse», який здебільшого перекладено як «знання», а не як «пізнання»» [Іващенко, Терлецький 2020: 218]. - А мене вражає таке нерозуміння простої логіки цього перекладацького рішення, зумовленого специфікою Кантового терміновжитку. Кантознавцям має бути відомо: «'Erkentnis' can either be translated as 'knowledge' or 'cognition'» [Thorpe 2015: 44] -

\footnotetext{
1 Числа стосуються тексту другого видання оригіналу з доданою передмовою до першого; враховано тільки іменники або початкові компоненти складних іменників - без таких випадків, як Mißverstand, verstanden, verständlich або vernünftig, vernünftigerweise, vernünfteln тощо.
} 
залежно від контексту. Український кантознавець, як уже сказано, ще й мав би бути обізнаним з українськими перекладами Канта - у супровідних текстах до них можна знайти відповідну інформацію: «Erkenntniss (стара орфографія - I. Б.) «пізнання» Кант часто вживає в значенні досить рідко в нього спотиканого Kenntniss «знання». (...)» [Бурковський 2004b: 186]. Автор нового англійського перекладу пише: «Erkenntnis can be a mere cognitive act, but it can also be knowledge in the fullest sense... It is the task of the reader to decide if it is one or the other, or both... It would hardly be helpful to follow Müller's tentative approach and to render Erkenntnis as both 'knowledge' and 'cognition' according to whether one or the other is appropriate in any given context. I have opted... for consistendy translating Erkenntnis as 'knowledge', thereby preserving in English an ambiguity...» [Weigelt 2007: XLVIII].

Обидві, як тепер модно казати, «стратегї̈» перекладу мають свій резон, і мій вибір цілком правомірний. Так постановив і семінар «Лабораторії наукового перекладу» 19 жовтня 2002 р.: знання, пізнання - залежно від контексту. Інша річ, що певні випадки такого розрізнення бувають дискусійними (виграшнішим тоді здебільшого є варіант знання - як такий, що містить і свою передумову, пізнання).

Але під впливом деяких фахівців - насамперед Віталія Терлецького (хоча не пригадую якогось аргумента поза сакраментальним «перекладати скрізь однаково») - я згодом пристав на його думку: «Erkenntnis, що там передавалося двояко... тут у всіх випадках перекладено як «пізнання»» [Бурковський 2004: 373] - нехай читач сам ламає голову. Однак таке рішення теж викликає сумніви - не вдаватимуся тут у детальніші міркування, як і в обговорення проблеми розрізнення das Erkenntnis i die Erkenntnis (рецензенти на неї просто не звертають уваги). Сказаного вже досить, щоб відкинути заувагу як неслушну.

4. «Сплутування трансцендентного й трансцендентального» [Іващенко, Терлецький 2020: 218]. Точніше, цей пункт інформує, що в чотирьох місцях замість трансцендентний стоїть трансцендентальний (але не навпаки). Додам, що основа transzendental- в оригіналі фігурує 517 разів, a transzendent- - 39. Відмінність між цими поняттями я засвоїв ще третьокурсником, але «поліпшувачі» перекладу, літред та коректорка, про неї не мали жодного уявлення. Хтось із них - не пригадую, хто саме - запам'ятав слово трансцендентальний, а здибаючи нечастотне трансцендентний, гадав, що то розтелепа-перекладач пропустив -аль-, і відповідно «виправляв». Дещо з тих «поліпшень» (інші приклади - не можу мати жодного споглядання замість не можу дати... чи несучого замість не сущого [Кант 2000: 113, 493]), на жаль, таки побачило світ.

Згадаю ще один прикрий випадок зі своєї перекладацької практики. Колись редакція «Всесвіту» доручила мені зробити зі шматка англомов- 
ної праці про Бекета (два розділи на кількадесят сторінок) на порядок коротший зв'язний і цікавий текст українською. Завдання я виконав - перетворив ті два розділи на два невеличкі есеї («Сценічна скульптура: беккетівське тіло» та «Мова парадоксу»), редакція, як мені згодом передано, була вдоволена, коректив було мало - але без спотворень не обійшлося. Щось перекрутив складач (комп'ютерів ми тоді ще не мали), щось редактори. Так, перший заголовок набрали більшим шрифтом, зробивши з двох текстів один, зі здеформованою архітектонікою. На жаль, виправлена верстка, яку я вчасно надіслав члену редколегії Миколі Рябчукові, десь чомусь загубилася, і та дефектна версія так і пішла в друк. Що мене особливо пройняло - те, що суб'єктний, суб'єктність скрізь обернулися на суб'єктивний, суб'єктивність [Таксіду 1991: 107, 108].

Але що ж - хай там хоч які причини, а чотириразова серйозна помилка - це невблаганний факт. Тож заувага - слушна, попри неслушне узагальнення.

5. «Геть у дивний спосіб перекладено одне з центральних понять Кантової теорії суб’єктивності «das Selbst» як «особистість»...» [Іващенко, Терлецький 2020: 219]. Знову нагнітання «викривального пафосу», не підкріпленого нічим серйозним. Насправді ж тут немає нічого навіть просто дивного. Ось як перекладає словник субстантивоване англ. (the) self, термінологічний еквівалент етимологічно тотожного нім. (das) Selbst: «власне “я”...; філос. особистість» [Балла... 2001: 241]. Про помилку тут не може йтися - щонайбільше про неточність. Не йдеться й про ключове поняття: у КЧР (2. видання) цей іменник виступає 9 разів, до того ж не завжди як термін [Willaschek... 2015 3: 2059]. «Поняття «die Personalität» так само перекладено як «особистість», що в даному випадку цілком слушно, хоча в цілому заплутає навіть уважного читача» [Іващенко, Терлецький 2020: 220]. Насправді ж якогось поважного заплутування від того, що ці два близькозначні терміни передано однаково, не буде - як i, скажімо, від передання В. Терлецьким Gemüt i Seele одним словом душа [Кант 2018: XXIX, 135]. Розмежувати переклад Personalität i Selbst, звісно, варто, але пропоновану рецензентом самість (радше відповідник нім. Selbstheit, англ. selfness, selfhood) прийняти важко: хіба denkendes Selbst - це «мисляча самість»?.. Заувагу відносимо до слушних, але неістотних.

6. « ... маємо дві істотні (?) невідповідності стосовно оригіналу. Поперше, «die Affektionen» тут перекладено як «враження іззовні», хоча раніше дієслівна форма цього поняття (affizieren) послідовно перекладалася як «впливати» чи «зазнавати впливу» [Кант 2000: 56, 60, 69 тощо]. Але водночас як «враження» перекладено також інше поняття «der Eindruck» [Кант 2000: 76], що, зрештою $є$ коректним, але однознач- 
но заплутує читача... По-друге, множина поняття «функція» в оригіналі чомусь стала одниною в перекладі» [Іващенко, Терлецький 2020: 220].

Чергове «тяжке звинувачення» - несправедливе. Неусунені через гострий дефіцит часу з першої половини тексту сліди того, як перекладач намацував найвдаліші версії - у даному разі латинізми афектувати (affizieren) і афекція (Affektion) - це, звісно, недоліки, але не надто серйозні. Збережені первісні робочі варіанти теж передають поняття більш-менш правильно, дієслівна форма (в активній і пасивній постатях), либонь, може вважатися навіть «легітимним» синонімом (аналогічно як у випадку Kausal- $\rightarrow$ причиновий/каузальний). Що ж до заплутування, то для цього тут ще менше підстав, ніж у попередньому випадку. Наведений один з двох наявних у книзі варіантів передання Affektion(en), враження ззовні - це hapax legomenon. Affektion i, за визнанням рецензентів, коректно перекладене Eindruck у Канта є синонімами (не завжди цілковитими, але в будь якому разі вони близькі значеннєво - див.: [Willaschek... 2015 1: 27]). Щодо числа іменника - цей недогляд якихось поважних наслідків не має, принаймні для притомного читача, на якого розраховано книгу. Отож і ця заувага - певною мірою слушна, але аж ніяк не істотна.

7. «Немає жодної послідовності в перекладі ключових для Кантової філософії термінів «die Einbildung» (уява/виображення), «die Einbildungskraft» (сила уяви/сила виображення), «die Vorstellung» (уявлення), «die Vorstellungskraft» (сила уявлення)» [Іващенко, Терлецький 2020: 220].

Жодної послідовності?

Einbildungskraft скрізь послідовно перекладено як уява (чи кращі ті варіанти, що пропонує рецензент - це вже інша тема).

Vorstellung послідовно перекладено як уявлення (і всі так перекладають). $€$, щоправда, кілька винятків (рецензенти їх, мабуть, і не помітили) - коли його вжито в архаїчному нині значенні Darstellung. I в новому польському перекладі, де Vorstellung назагал передано звичним przedstawienie, бачимо й «prezentacją [Vorstellung] intelektu i reguł jego koniecznego użycia in concreto» (B 78) [Kant 2013: 153] (пор. «Jest ona prezentacją [Darstellung] czystych pojęć intelektualnych» (B 168) [Kant 2013: 233]). Це чіткіше передає Кантову думку - хоча можна було б обійтися й самим лише przedstawienie, значеннєво ширшим за укр. уявлення, аналогічно як у російському (представление) та інших перекладах - але в українському стовідсотково одноманітне передання цього слова неможливе.

Einbildung перекладено то як уявлення, то якуява - але це не якась непослідовність, це зумовлено контекстом, тобто рівнем термінологічної строгості й чіткості в Канта. Хто не знає, що це слово може вживатись і 
в тому, і в тому значенні (як і його грецький еквівалент: пор. розвинена фантазія і химерні фантазії) - може пересвідчитися зі словників.

Тільки Vorstellungskraft перекладено справді непослідовно (докладніше див. вище). 3 огляду на неслушність віднесення цього терміна до «ключових для Кантової філософії» (насправді - хіба що для Вольфової), і зокрема КЧР, де його вжито лише 7 разів - вада не критична.

Отож інвектива «Такий термінологічний хаос не просто спантеличує читача, а унеможливлює розуміння логіки вжитку ключових термінів у всьому тексті «Критики»» [Іващенко, Терлецький 2020: 221) - це нонсенс. Уся заувага тягне не більше як на (незначною мірою) слушну, але неістотну.

8. «Дивує також те, що сам перекладач не дотримується рішень, логіку яких іноді пояснює в примітках. Приміром, у примітці № 10 [Кант 2000: 485] пояснюється, що словом «душевність» передається Кантове «das Gemüt», проте цей термін перекладено у цьому українському виданні Канта то як «душевність» [Кант 2000: 58], то як «душа» [Кант 2000: 60]» [Іващенко, Терлецький 2020: 221]. Хтось із моїх опонентів щойно картав мене за однину - а я маю дорікнути авторові цього пасажу за множину: «не дотримується (можна подумати - завжди) рішень (можна подумати - усіх)». Таких рішень наведено аж 1 (одне), і прикладів недотримання - 1 (один): доказовість, м'яко кажучи, недостатня. Хоча випадків такого передання того іменника можна знайти більше (B. Терлецький, до речі, й сам передає його двояко: [Кант 2018: 111, 135]). Це або недоробки, спричинені цейтнотом - неусунення первісного робочого варіанту (що, однак, не створює якихось поважних наслідків), або ж відбиття Кантового терміновжитку. Як зазначає Р. Айслер, у КЧР Gemüt нерідко має значення 'свідомість' [Eisler 1984: 182], тож душевність там може зовсім не пасувати. Оцінка зауваги - як і попередньої.

9. «... «досвід ніколи не дає своїм судженням істинної або строгої загальності - лише умовну й відносну (через індукцію)» [Кант 2000: 40]. Тут «angenommen» не має значення умовності, натомість означає «припущений»... А от переклад прикметника «komparativ» як «відносний» (у німецькій «відносний» - «relativ») раціонально пояснити дуже важко, адже означає він «порівняльний», тобто йдеться про загальність, якої досягають через порівняння явищ у досвіді, а не про відносність загальності, адже загальність не може бути відносною (?!)» [Іващенко, Терлецький 2020: 221].

Нагадаю опонентам: у школі (принаймні вищій) вчать, що загальність буває цілковитою, граничною (= безмежною), абсолютною; і буває обмеженою, відносною. Переважна більшість загальних понять якраз і $\epsilon$ відносно загальними: у відношенні до одних понять - більш, а у відношенні до інших - менш загальними. А переклад komparativ як відносний 
пояснити дуже легко. Порівняно (не порівняльно) загальний - це те саме, що відносно загальний. Академічний тлумачний словник (опускаю приклади):

«ПОРІВНЯНИЙ ... 2. у знач. прикм. Який визначається в порівнянні, у зіставленні з чим-небудь іншим; відносний (виділення моє - І. Б.)... // Не цілковитий, не повний ...»[Артем'єва... 1976: 258].

У Канта якраз ідеться про відносність, неповноту емпіричної (індуктивної) загальності, що проявляється в порівнянні, співвіднесенні її 3 апріорною, абсолютною загальністю. Найближче до букви ориґіналу був би варіант порівняний (витлумачення komparativ як порівняльний «йдеться про загальність, якої досягають через порівняння явищ у досвіді» - навряд чи можна визнати логічним тут, де Кант протиставляє апріорну і емпіричну загальність, указуючи їх контрастні характеристики), але синонім відносний мені бачиться значно зрозумілішим для читача.

Хибним є твердження, ніби angenommen не має тут значення умовності - воно наявне й у семантиці висуненого рецензентом варіанта припущений (зі стилістичних міркувань відповідне значення цього слова зазвичай передають синонімом гаданий). Angenommen означає 'прийнятий', зокрема в сенсі 'умовлений', звідки й 'умовний' (напр., angenommener Gegner - умовний противник): ідеться про не лише гадано (нім. vermutlich) загальне (хоча цей значеннєвий компонент теж присутній), а й трактоване як загальне, тобто про умовно загальне.

Сподіваюся, викладеного досить для висновку: зміст Кантової думки в обох моментах передано цілком адекватно, тобто заувага - неслушна.

\section{Відповіді на зауваження 2-го підрозділу (“Синтаксис Канта»)}

1. «Адже якась метафізика у світі завжди була й, певно, буде надалі, а разом із нею - і діалектика чистого розуму, позаяк вона природно їй притаманна» [Кант 2000: 32]. Рецензент: «Тут ми маємо два конкурентні варіанти. Діалектика чистого розуму є природною або для метафізики (Metaphysik), або для чистого розуму (reine Vernunft)... Ось як це речення переклали автори останнього перекладу англійською мовою... (обрали другий варіант - I. Б.). Систематично це бездоганне рішення, адже джерелом діалектики за Кантом є саме розум... I якщо синтаксично обидва варіанти можливі, то систематично «ihr» слід перекласти саме як «для розуму», адже лише розум має природу (?!)» [Іващенко, Терлецький 2020: 222].

Уже за такий аргумент цей закид варто кваліфікувати як неслушний, хоча обстоювану моїм опонентом думку саму по собі так назвати не можна: вона - дискусійна. Утім, дискутувати особливо нема про що (не торкаємось інших аспектів цього речення). Якщо другий варіант бездоганний, то й перший - також: діалектика чистого розуму, за Кантом, 
притаманна метафізиці, щонайприроднішим чином, адже метафізика $є$ породженням того ж таки чистого розуму; і цей варіант має багато прихильників. Йому віддано перевагу:

- в англійському перекладі, що з'явився після того «останнього»: «Some kind of metaphysics has always existed and will always exist, but with it a naturally given [за змістом - їй] dialectic of pure reason» [Kant 2007: p. 26];

- майже в усіх російських перекладах і редакціях, від 1867 до 2006, другий варіант - лише в сумнозвісного Миколи Соколова (більшість цих версій наведено в: [Кант 1999: с. 44]);

- у новому польському перекладі Мирослава Желязного: «Zawsze była na świecie jakaś metafzyka i zawsze też jakaś będzie, a wraz z nią będzie i dialektyka czystego rozumu, która łączy się z nią w sposób naturalny» [Kant 2013: s. 63].

Гадаю, цих ілюстрацій вистачить. Комусь більше подобається той варіант, комусь інший, але дуже малоймовірно, щоб у виниклій із цього приводу дискусії котрась сторона спромоглася змусити іншу до такого неприємного (для багатьох - неприйнятного) акту, як капітуляція. (Мені перший варіант бачиться кращим (логічно та стилістично), але це не обов'язково означає, що Кант мав на увазі саме його).

Обговорюваний закид до того ж вочевидь неістотний - бо про якесь спотворення головної Кантової думки тут не може йтися. Отож з огляду на нерозуміння чи неврахування викладеного щойно, як і надзвичайно хибний аргумент, заувагу цілком можна кваліфікувати просто як неслушну.

2. «...стикаємося з помилкою, яка радикально змінює Кантову думку: «...уявлення було б або неможливим, або принаймні не було б для мене нічим» [Кант 2000: 105].

Оригінал:

«... die Vorstellung würde entweder unmöglich, oder wenigstens für mich nichts sein» (KrV, B 131-132) [Kant 1998: 178].

Як бачимо, в українському перекладі з'явилася заперечна частка «не», яка в поєднанні з «нічим» утворює подвійне заперечення, а отже, цілковито змінює Кантову думку. Адже в німецькому оригіналі йдеться про те, що без супроводу «Я мислю» наших уявлень вони були би для нас нічим, тоді як в українському перекладі, навпаки... (не було б для мене нічим = було би чимось)... Ясно, що така помилка цілковито змінює напрямок Кантового аргументу... [Іващенко, Терлецький 2020: 222-223].

Хибність цих звинувачень передовсім у тому, що українську мову сплутано з німецькою. Якщо німці чи англійці кажуть (буквально): був ніде, цікавився нічим, то слов'яни додають заперечну частку: не був ніде..., хоч вона з логічного погляду недоречна, бо формально дає протилеж- 
ний зміст. Професор філософії Марек Росяк пише: «Видається, що явище подвійного заперечення в польській мові аж ніяк не свідчить про те, що праслов'яни не знали логічного закону подвійного заперечення - радше про те, що вони відмовлялись говорити, а напевне й думати, ніби ніщо в який-небудь спосіб iснує» [Rosiak 2011: 197] ${ }^{1}$. (Щоправда, трапляються й випадки відсутності того зайвого не - і тут його теж, либонь, можна (що не означає - неодмінно треба) опустити). Заувага - неслушна.

3. Твердження щодо помилковості перекладу eine Erkenntnis von Gegenständen..., die lediglich auf der Synthesis der Vorstellungen beruht $\rightarrow$ знання про предмети, які грунтуються виключно на синтезі уявлень базується на хибному витлумаченні форми знання: насправді вона позначає тут множину - назагал цілком правомірна перекладацька трансформація, як i, скажімо, у заголовку § 22: «Категорії не мають...» [Кант 2000: 112], хоча в ориґіналі стоїть однина («Die Kategorie hat...» [Kant 1998: 188]) - бо йдеться не про одну категорію, а про всі, тобто формальна однина насправді має тут значення збірності. Подібно й у цьому випадку - за змістом радше не одне знання про багато предметів, а різні знання про різні предмети.

Та попри те маємо тут двозначність - хтось може зрозуміти й хибно, як описано в заувазі. Це зумовлено насамперед недосконалістю нашої ординарної пунктуації - нема способу позначати певні моменти синтаксичної структури: \{знання про предмети\}, які грунтуються... - а не знання про \{предмети, які грунтуються...\}. І ще один чинник - омонімія: століття тому кодифікатори українського мовного стандарту узаконили нерозрізнення аж п'ятьох членів деклінаційної парадигми таких іменників (називного та знахідного відмінків як однини, так і множини, плюс родового однини - скрізь знання), відмовившися від поширеної в багатьох регіонах форми однини типу знаннє, життє. Отож така трансформація хоч і не помилкова, але радше невдала. 3 огляду на це заувагу можна вважати в деякому сенсі слушною, і віднести її дещо умовно до графи слушних, але неістотних - як рівновартісну.

4. Сенс цього речення, на мій погляд, потрібно ще вточнювати, але гаразд - умовно визнаю заувагу слушною. Зверну увагу, що тут рецензенти не кваліфікують помилку як тяжку.

5. Заувага слушна: не містять лише замість містять лише - недогляд, помітний навіть нефахівцеві з середнім рівнем знання мови.

6. Не можна погодитися з твердженнями: «В українському перекладі відносний займенник «welche» пов'язано з формою («нею») явища, яка обмежує категорії. Це, звісно, прямо суперечить Кантовій аргументації,

\footnotetext{
${ }^{1}$ Наведення цього спостереження про парменідівську рису мислення наших предків, досі відбиту в граматиці слов'янських мов, аж ніяк не означає згоди з авторовим паплюженням діалектики.
} 
адже застосування категорій обмежено явищами, а не формою явищ. Ба більше, категорії як чисті поняття розсуду разом із часом і простором як формами чуттєвості і становлять форму явища... 3 українського ж перекладу випливає, що категорії як форма явища обмежені формою явища, що, звісно, не має жодного сенсу» [Іващенко, Терлецький 2020: 225]. 1) переклад відхиляється тут від оригіналу, але не настільки, щоб суперечити йому, адже якщо застосування категорій обмежене явищами, то це означає також - формою явищ; 2) навряд чи коректно стверджувати, що категорії разом із часом і простором становлять форму явища (незрозуміло, чи рецензент бачить тут аж дві форми, а чи компоненти одної-єдиної); 3) з українського перекладу не випливає, що категорії обмежені формою явища як форма явища - це висновує рецензент зі своєї сумнівної характеристики категорій (ще й досить виразно приписуючи тут явищу таки дві форми), що її в перекладі не знайти; 4) навіть із погляду тієї сумнівної характеристики навряд чи можна вважати позбавленою сенсу думку, що одна форма (чи компонент форми) явища певним чином обмежує іншу (інший). Але поза тим заувага слушна: auf welche, als ihre einzigen Gegenstände $\rightarrow$ нею... як своїм єдиним предметом замість ними... як своїми єдиними предметами - очевидний недогляд, хоча кардинального спотворення Кантової думки тут немає.

7. Заувага слушна, переклад речення належно не продуманий.

8. Тут, подібно як у II.3., ідеться про двозначну конструкцію не лише $A$, а й $B$, тобто $C$. Рецензент приписує мені варіант не лише $A$, a й $\{B$, тоб$m o C\}$, але за традиційною нормою - сумнівні моменти тлумачити на користь звинуваченого - мав обрати інший, $\{$ не лише $A$, а й $B\}$, тобто $C .3$ тих самих мотивів, що й у зазначеному пункті (вказано хоч і не помилку, але невдале формулювання) заувагу варто віднести до слушних, але неістотних (прирівняних до таких).

9. Цю заувагу з давньої рецензії Віталія Терлецького вже обговорено вище, вона слушна в головному. Неслушним, одначе, слід визнати твердження: «Тут ми маємо той показовий випадок, коли кантознавча і текстологічна компетенції просто необхідні для виконання перекладу» [Іващенко, Терлецький 2020: 226]. Вони потрібні, щоб належно прокоментувати це місце - але не для коректного перекладу, тобто уникнення очевидної помилки - diese a priori möglich sein $\underline{\text { soll }} \rightarrow$ вони мають бути можливими а priori замість він має бути можливим... (як і пропуску überhaupt). «Показові випадки» зазначеного типу, безперечно, $\epsilon$ - але цей до таких не належить. У цьому випадку проблема полягала головно в умовах праці.

Дві ненумеровані зауваги щодо термінології.

А) «Слід констатувати також певну тенденцію до модернізації Кантової термінології, що безперечно може спантеличити сучасного читача. Усе-таки Кант був автором XVIII ст., тому коли він пише про «трансцен- 
дентальне вчення про метод» (KrV B 733), а в українському перекладі стоїть «трансцендентальна методологія» [Кант 2000: 405], то можна дійти до думки, мовляв, уже Кант був теоретиком методології» [Іващенко, Терлецький 2020: 226].

Таку «модернізацію» бачимо вже в перекладах того ж таки XVIII ст.: methodologia transscendentalis [Kant 1796: 487 et passim] і першої половини наступного: méthodologie transcendentale [Kant 1845 2: 405] - це друге видання, на жаль, не маю зараз доступу до першого (1835-1836): гадаю, і там так само; аналогічно - у першому перекладі другої «Критики» на іншу живу мову: méthodologie de la raison pure pratique [Kant 1848: 371]. Що вже казати про «модернізаторів» XX ст., як феноменолог Роман Інгарден: metodologia transcendentalna [Kant 1986 II: 447] чи словацький історик філософії Теодор Мюнц: transcendentálna metodológia [Kant 1979: 432]. Німецьке Methodenlehre - синонім, напівкалька латинського терміна methodologia, грецького походження. Ми такого термінологічного еквівалента не маємо, цілком обходимося латинсько-грецьким. «Трансцендентальне вчення про метод» і подібні спроби буквального тлумачення - незграбні й не цілком адекватні.

Закид - і неістотний, і неслушний.

Б) «Коли Кант не без скепсису (без жодного скепсису, суто критично - I. Б.) пише про «трансцендентальне вчення про душу [Seelenlehre][»] (KrV B 403), спеціально увиразнюючи догматичний характер цієї доктрини, то український читач у цьому місці побачить лише «трансцендентальну психологію» [Кант 2000: 238], хоча в іншому місці Кант вживає поняття «психологія» [Psychologie] (В 401), яке, ясна річ, українською відбито знову як «психологія» [Кант 2000: 237]» [Іващенко, Терлецький 2020: 226].

Seelenlehre - усього лише питомий німецький еквівалент терміна грецького походження Psychologie. У Канта (і не тільки в нього) ці термінологічні синоніми цілком взаємозамінні. Якщо слова «увиразнюючи догматичний характер цієї доктрини» мають означати, що вжиття Кантом питомого варіанта якимось чином слугує тому увиразненню, то це - лише суб'єктивний (i бездоказовий) погляд рецензента. Ми подекуди вживаємо два синонімічні терміни (з класичних мов і питомий, напр. каузальність і причиновість) там, де Кант уживав один, але частіше чинимо навпаки, як-от у цьому випадку, оскільки не маємо свого питомого відповідника запозиченого терміна (інтернаціоналізму), і до цього треба ставитися спокійно: термінологічна синонімія - то радше розкіш, ніж дійсна потреба. (У німецькій мові, не тільки філософській, були сильніші пуристичні тенденції, прагнення до онімечування чужомовних термінів). Спроби перекладати буквально німецький термін невиправдані - вже з огляду на небезпеку того, про що полюбляють згадувати мої опоненти (хоча радше без достатніх підстав) - дезорієнтування читача, 
надто недосвідченого, студента, у якого може виникнути уявлення про якесь таємниче «вчення про душу», відмінне від психології (і не тільки через це). Отож у КЧР-2000 тут - слушне рішення, як і в низці інших перекладів, зокрема англійських (тут і відомий рецензентам Норман Кемп Сміт): «transcendental psychology» (В 403) [Kant 2007: 319; Kant 2007a: 331] - не буду розширювати далі список посилань.

Із цієї ж рубрики - зауваження одному з нинішніх рецензентів мого перекладу, що Кантове Sittenlehre слід передавати як етика, а не вчення про звичаї [Бурковський, et al. 2018: 123].

Оцінка цієї претензії до перекладу - як і попередньої.

\section{Висновки}

Отже, із $20(9+9+2)$ зауваг слушними (і більш-менш істотними) виявляються 8 - решту читач полічить сам. А що кожен повтор тієї самої помилки зазвичай рахується як окрема помилка, то додамо ще 3 й 2 таких випадки з зауваг I.2. і I.4. ${ }^{1}$ - виходить 13 дійсних більш-менш серйозних хиб перекладу (хоча далеко не всі вони являють собою істотне перекручення чи затемнення важливої Кантової аргументації), пересічно одна на 47 традиційних умовних сторінок. Навряд чи хто з неупереджених осіб не погодиться, що цього аж ніяк не достатньо для підтвердження тези про його незадовільність. Наважуся стверджувати, що коректне її доведення просто неможливе - бо ця упереджена теза не відповідає дійсності. (€, щоправда, один мікромасив, що заслуговує незадовільної оцінки - словничок латинізмів, похапцем скопійований з російського дефектного академічного видання). Рецензенти могли б знайти в книзі вдвічі (це реально) чи втричі більше дійсних помилок - але й цього було б дуже замало для досягнення їхної мети.

Загалом безпідставним виявляється звинувачення «непослідовність перекладу ключових Кантових термінів» [Іващенко, Терлецький 2020: 227]: одиничні недогляди на таке не заважують; щодо деяких менш важливих це трапляється - але без якихось поважних наслідків, принаймні рецензенти не продемонстрували жодного (тільки декларували неминучість «катастрофічного» сценарію за будь-яких випадків варіативності термінів - що є великим перебільшенням).

Неуспіх спроби рецензентів зумовлений насамперед нестачею вагомого матеріалу, з цим може бути пов'язана й продемонстрована ними відсутність якоїсь чіткої переконливої методики оцінювання рецензо-

${ }^{1}$ Щоб не вдаватися в докладніші підрахунки, нецікаві для мене, дозволю собі знехтувати тією обставиною, що й ще деякі зауваги рецензентів містять по більш ніж одній претензії до перекладу - хоч відповідні підрахунки означали б додаткові очки на мою користь, позаяк ті претензії виявилися неслушними або/та неістотними. 
ваного тексту - це стосується як термінологічної частини, так і рецензії в цілому. Гостра риторика («термінологічний хаос» і т. ін.) з широкими беззастережними узагальненнями за настільки слабкої обгрунтованості є ознакою видавання бажаного за дійсне.

Примарними є масштабні синтаксичні некоректності, через які (вкупі з термінологічними негараздами - як ми бачили, теж радше примарними) читач нібито «теоретичну філософію Канта за наявним українським перекладом зрозуміти не зможе» [Іващенко, Терлецький 2020: 227]: це має означати грубі помилки в якійсь значній частині синтагм, тимчасом наведено кілька речень - із кількох тисяч, що просто несерйозно як на такий присуд. Це ще могло б справляти враження, якби ті кілька речень були з сусідніх сторінок - і то не було б певності, що вибраний уривок $\epsilon$ типовим; а те, що бачимо тут насправді - знову ознака видавання бажаного за дійсне.

Не підтверджується й думка про фатальну некомпетентність перекладача. Переважна більшість відзначених дійсних помилок - I.1., усі 7 випадків I.2 й I.4; II.5, II.9, тобто 10 із 13 (77\%) - це очевидні недогляди. Це означає, що головна причина хиб - не та, яку вказують рецензенти, а та, про яку вони не згадують жодним натяком - «вимушений поспіх і взагалі... квазі-екстремальні умови», в яких готувалося видання [Бурковський 2004a: 183]. 3 нею, принаймні частково, пов'язані й решта помилок, що їх генеза не така ясна.

Насправді рецензія показує лише те, що читач може не зрозуміти правильно деяких місць обговорюваного перекладу. Але студент не зрозуміє й багатьох місць, переданих цілком коректно (деяких не розуміють і фахівці). Що ж до помилок, то знейтралізувати їх, поки ще немає другого видання, допоможе їхній реєстр. Більшість причетних до кантознавства викладачів англомовних університетів мали власні списки коректив до авторитетного перекладу [McLaughlin 1999: 359]. Короткий список поправок до КЧР-2000 я віддавна намагався поширювати через видавництво й книгарні, довший викладу незабаром у мережі - маю подякувати рецензентам за внесок до нього. При цій нагоді також складаю вибачення перед читачами.

Ця публікація матиме продовження: розгляд решти відомих мені претензій до КЧР-2000, а також переконування читачів, що переклад, попри наявні в ньому огріхи, не такий уже й поганий. Роблю я це головно шляхом демонстрації - численні цитати з Канта тих фахівців, що воліють перекладати самотужки, у порівнянні з відповідними місцями обговорюваного тексту, і ще дещо. Матеріал великий, але маю надію, що він побачить світ досить скоро. 


\section{Посилання:}

[Аноним] (1937). Предисловие к «Науке логики» Гегеля. Гегель, Г.В.Ф. Наука логики. Перевод Б.Г. Столпнера. Сочинения. T.V. Москва: Соцэкгиз, V-XII.

Артем'єва, Л.К. (ред.) та ін. (1976). Словник української мови: в 11 томах. Том 7. Київ: Наукова думка.

Балла, М.І., та ін. (2001). Короткий англо-українсько-російський словник наукової лексики. Київ: Грамота.

Брушлинский, В.К. (1937). Примечания. Гегель, Г.В.Ф. Наука логики. Перевод Б.Г. Столпнера. Сочинения. T.V. Москва: Соцэкгиз, 697-709.

Бурковський, I. (1995). Що робити з логікою Гегеля? Генеза, 1(3), 43-51. https://nas. academia.edu/IhorBurkowsky

Бурковський, I. (2000). Примітки. Кант, I. Критика чистого розуму / пер. $з$ німецької та примітки Ігоря Бурковського. Київ: Юніверс, 483-490.

Бурковський, I. (2004). Від перекладача. Кант, І. Рефлексії до Критики чистого розуму / пер. з німецької й латини [післямова] та примітки І. Бурковського. Науковий редактор А. Лой. Київ: Юніверс, 372-374.

Бурковський, I. (2004а). Розбудовуючи українську кантіану Кант, I. Критика практичного розуму / пер. з німецької, примітки та післямова Ігоря Бурковського. Науковий редактор Анатолій Єрмоленко. Київ: Юніверс, 179-183.

Бурковський, I. (2004b). Примітки. Кант, I. Критика практичного розуму / пер. з німецької, примітки та післямова Ігоря Бурковського. Науковий редактор Анатолій Єрмоленко. Київ: Юніверс, 184-236.

Бурковський, I. (2021). Із сьогоденних проблем опанування Геґелевої спадщини: «Феноменологія духа» в українському переданні. Філософська думка, 2, 114-130.

Бурковський, І., Єрмоленко, А., Кебуладзе, В., Терлецький, В. (2018). До третьої «Критики» Канта. Філософська думка, (6), 118-124.

Жучков, В.А. (1999). От издателя. Кант, И. Критика чистого разума / пер. с нем. Н.О. Лосского с вариантами пер. на рус. и европ. языки. Москва: Наука, 5-11.

Іващенко, I., \& Терлецький, В. (2020). Значливість перекладу для філософської освіти (на прикладі українського перекладу «Критики чистого розуму» Імануеля Канта). Філособія освіти, 26(1), 211-229.

Кант, И. (1964). Критика чистого разума. Перев. Н.О. Лосского. Ред. М. Иткин. Собрание сочинений в шести томах. Том 3. Москва: Мысль.

Кант, И. (1994). Критика чистого разума. Перев. Н.О. Лосский. Ред. И.С. Андреева. Собрание сочинений в восьми томах. Том 3. Москва: Чоро.

Кант, И. (1994а). Критика чистого разума / пер. с нем. Н. Лосского сверен и отредактирован Ц. Г. Арзаканяном и М. И. Иткиным; примеч. Ц. Г. Арзаканяна. Москва: Мысль.

Кант, И. (1999). Критика чистого разума / пер. с нем. Н.О. Лосского с вариантами пер. на рус. и европ. языки. Москва: Наука.

Кант, И. (2006). Критика чистого разума: в 2 ч. Ч. 1 / пер. с нем. под ред. Б. Бушлинга, Н. Мотрошиловой. Сочинения на немецком и русском языках. Том 2, ч.1. Москва: Наука.

Кант, I. (2000). Критика чистого розуму / пер. з нім. та примітки І. Бурковського. Київ: Юніверс.

Кант, I. (2018). Пролегомени до кожної майбутньої метафізики, яка може постати як наука. Вид. 2-ге, уточн. і доп. / пер. з німецької... В. Терлецького. Відп. редактор В. Кебуладзе. Харків: Фоліо. 
Ковальчук, Г.І. (2001). Апарат книги. Енциклопедія Сучасної України. Том 1. [б. м.]: Координаційне бюро ЕСУ НАН України.

Мінаков, М. А. (2007). Історія поняття досвіду: Монографія. Київ: Вид. ПАРАПАН.

Савчин, В. (2008). Анатолій Онишко: «Якщо варто робити взагалі...». Всесвіт, 3-4, 206-211.

Таксіду, О. (1991). Сценічна скульптура: беккетівське тіло / пер. з англ. І. Бурковського. Всесвіт, 10 (754), 104-108.

Терлецький, В. (2000). Кант в українському прочитанні. Книжник-review, 6 (6), 6.

Терлецький, В. (2005). «Пролегомени» I. Канта: трансцендентальна філософія in statu nascendi. Кант, І. Пролегомени до кожної майбутньої метафізики, яка може постати як наука / пер. з німецької, вступна стаття, коментарі і примітки Віталія Терлецького. Науковий редактор Кебуладзе В. I. Київ: ППС-2002, I- LIV.

Терлецький, В. (2006). Кант українською: проблеми й дилеми. Український гуманітарний огляд, (12), 135-153.

Терлецький, В. (2015). Український погляд на Кантову антропологію. Філософська думка, (2), 67-71.

Терлецький, В. (2018). «Пролегомени» I. Канта: трансцендентальна філософія in statu nascendi. Кант, I. Пролегомени до кожної майбутньої метафізики, яка може постати як наука. Вид. 2-ге, уточн. і доп. / пер. з німецької... Віталія Терлецького. Відповідальний редактор В. Кебуладзе. Х.: Фоліо, III- LXX.

Чумак, В.В., та ін. (2013). Словник украӥнської мови: у двадцяти томах. Том 4. Київ: Наукова думка.

Шпетт, Г. (1904). Иммануил Кант. Критика чистого разума. Перевод Н.М. Соколова... Вопросы философии и психологии, 74(4), 550-564.

Adelung, J. Ch. (1811). Grammatisch-kritisches Wörterbuch der Hochdeutschen Mundart. 1. Teil. Wien: V.Ph. Bauer.

Eisler, R. (1984). Kant Lexikon. Georg Olms Verlag.

Glare, P. G. W. [ed.] (2012). Oxford Latin Dictionary (2nd edition). Oxford University Press.

Grimm, J. \& W. (1862). Deutsches Wörterbuch. Leipzig: S.Hirzel. Bd. III.

Ingarden, R. A priori Knowledge in Kant vs. a priori Knowledge in Husserl. Dialectics and Humanism, 1(1), 5-18.

Kant, I. (1796). Immanuelis Kantii Opera ad philosophiam criticam. Volumen primum, cui inest Critica rationis purae. Latine vertit Fredericus Gottlob Born. Lipsiae, impensis E.B. Schwickerti.

Kant, E. (1845). Critique de la raison pure. Seconde édition en français, retraduite sur la première édition allemande... par J. Tissot. Tome 2. Paris : Librairie philosophique de Ladrange.

Kant, E. (1848). Critique de la raison pratique; précédée des Fondements de la métaphysique des mœurs; traduit de l'allemand par J. Barni. Paris: Ladrange.

Kant, I. (1904). Kritik der reinen Vernunft (2-te Aufl. 1787). Kant's gesammelte Schriften: Herausgegeben von der Königlich Preußischen Akademie der Wissenschaften. Bd. 3. Berlin: PAW.

Kant, I. (1979). Kritika čistého rozumu. Preložil... PhDr. Teodor Münz. Bratislava: Pravda. Kant, I. (1986). Krytyka czystego rozumu. Przeł. R. Ingarden. T. I-II. Wyd. II. Warszawa: PWN. Kant, I. (1998). Kritik der reinen Vernunft. Hrg. v. Jens Timmermann. Hamburg: Meiner. 
Kant, I. (2007). Critique of Pure Reason. Translated, edited, and with an Introduction by Marcus Weigelt. Based on the translation by Max Müller. Penguin Books.

Kant, I. (2007a). Critique of Pure Reason. Translated by Norman Kemp Smith. Revised Second Edition. Palgrave Macmillan.

Kant, I. (2013). Krytyka czystego rozumu. Przekład: Mirosław Żelazny. Dzieła zebrane. Tom 2. Toruń: Wydawnictwo Naukowe Uniwersytetu Mikołaja Kopernika.

McLaughlin, P. (1999). [Review of:] Immanuel Kant, Kritik der reinen Vernunft, edited by Jens Timmermann, Felix Meiner Verlag, Hamburg, 1998... Erkenntnis, 51, 357-363.

Rosiak, M. (2011). Dialektyka Hegla. Krytyczny komentarz do głównych tekstów metafizycznych. Kraków: Universitas.

Thorpe, L. (2015). The Kant Dictionary. Bloomsbury philosophy dictionaries.

Weigelt, M. (2007). Introduction. Kant, I. Critique of Pure Reason. Translated, edited, and with an Introduction by Marcus Weigelt. Penguin Books, XV-LXIX.

Willaschek, M., Stolzenberg, J., Mohr, G., Bacin, S. [Herausgegeber] (2015). Kant-Lexikon. Bd. 1-3. Berlin: De Gruyter.

Żelazny, M. (2013). Od tłumacza. Kant, I. Krytyka czystego rozumu. Przekład: Mirosław Żelazny. Dzieła zebrane. Tom 2. Toruń: Wydawnictwo Naukowe Uniwersytetu Mikołaja Kopernika, 7-28.

\section{References:}

Adelung, J. Ch. (1811). Grammatisch-kritisches Wörterbuch der Hochdeutschen Mundart. 1. Teil. Wien: V.Ph. Bauer.

[Anonymous] (1937). Preface to Hegel's Science of Logic. Hegel, G.V. F. Science of logic / transl. by B.G. Stolpner. Works. T.V. Moscow: Sotsekgiz, V - XII. [In Russian].

Artemyeva, L. K. (ed.) and others. (1976). Dictionary of the Ukrainian language: in 11 volumes. Volume 7. Kyiv: Naukova dumka. [In Ukrainian].

Balla, M. I., and others. (2001). A short English-Ukrainian-Russian dictionary of scientific terms. Kyiv: Diploma. [In Ukrainian].

Brushlinsky, V. K. (1937). Notes. Hegel, G.V. F. Science of logic / transl. by B.G. Stolpner. Works. T.V. Moscow: Sotsekgiz, 697-709. [In Russian].

Burkovsky, I. (1995). What to do with Hegel's logic? Heneza, 1(3), 43-51. https: //nas. academia.edu/IhorBurkowsky. [In Ukrainian].

Burkovsky, I. (2000). Notes. Kant, I. Critique of pure reason / transl. from German and notes by I. Burkovsky. Kyiv: Universe, 483-490. [In Ukrainian].

Burkovsky, I. (2004). From the translator. Kant, I. Reflections to the Critique of Pure Reason / transl. from German and Latin[, afterword] and notes by I. Burkovsky. Scientific editor Anatoliy Loy. Kyiv: Universe, 372-374. [In Ukrainian].

Burkovsky, I. (2004a). Building the Ukrainian Kantian. Kant, I. Critique of practical reason / transl. from German, notes and afterword by I. Burkovsky. Scientific editor A. Yermolenko. Kyiv: Universe, 179-183. [In Ukrainian].

Burkovsky, I. (2004b). Notes. Kant, I. Critique of practical reason / transl. from German, notes and afterword by I. Burkovsky. Scientific editor A. Yermolenko. Kyiv: Universe, 184-236. [In Ukrainian].

Burkovsky, I. (2021). Some actual problems of mastering Hegel's legacy: "Phenomenology of Spirit" in Ukrainian translations. Filosofska dumka, (2), 114-130. [In Ukrainian]. 
Burkovsky, I., Yermolenko, A., Kebuladze, V., \& Terletsky, V. (2018). To the third "Critique" of Kant. Filosofska dumka, 6, 118-124. [In Ukrainian].

Chumak, V.V., and others (2013). Dictionary of the Ukrainian language: in twenty volumes. Volume 4. Kyiv: Naukova dumka. [In Ukrainian].

Eisler, R. (1984). Kant Lexikon. Georg Olms Verlag.

Glare, P. G. W. [ed.] (2012). Oxford Latin Dictionary (2nd edition). New York: Oxford University Press.

Grimm, J. \& W. (1862). Deutsches Wörterbuch. Leipzig: S.Hirzel. Bd. III.

Ingarden, R. A priori Knowledge in Kant vs. a priori Knowledge in Husserl. Dialectics and Humanism, 1(1), 5-18.

Ivashchenko, I., \& Terletsky, V. (2020). The significance of translation for philosophical education (on the example of the Ukrainian translation of Immanuel Kant's Critique of Pure Reason). Philosophy of Education, 26(1), 211-229. [In Ukrainian].

Kant, I. (1796). Immanuelis Kantii Opera ad philosophiam criticam. Volumen primum, cui inest Critica rationis purae. Latine vertit Fredericus Gottlob Born. Lipsiae, impensis E.B. Schwickerti.

Kant, E. (1845). Critique de la raison pure. Seconde édition en français, retraduite sur la première édition allemande... par J. Tissot. Tome 2. Paris : Librairie philosophique de Ladrange.

Kant, E. (1848). Critique de la raison pratique; précédée des Fondements de la métaphysique des mœurs; traduit de l'allemand par J. Barni. Paris : Ladrange.

Kant, I. (1904). Kritik der reinen Vernunft (2-te Aufl. 1787). Kant's gesammelte Schriften: Herausgegeben von der Königlich Preußischen Akademie der Wissenschaften. Bd. 3. Berlin: PAW.

Kant, I. (1964). Critique of Pure Reason. Transl. N.O. Lossky. Ed. M. Itkin. Collected works in six volumes. Volume 3. Moscow: Mysl. [In Russian].

Kant, I. (1979). Kritika čistého rozumu. Preložil... PhDr. Teodor Münz. Bratislava: Pravda.

Kant, I. (1986). Krytyka czystego rozumu. Przeł. R. Ingarden. T. I-II. Wyd. II. Warszawa: PWN.

Kant, I. (1994). Critique of Pure Reason. Transl. N.O. Lossky. Ed. I.S. Andreeva. Collected Works in eight volumes. V. 3. Moscow: Choro. [In Russian].

Kant, I. (1994a). Critique of Pure Reason / transl. by N. Lossky verified and edited by Ts. G. Arzakanyan and M. I. Itkin; notes by Ts. G. Arzakanyan. M.: Mysl.Kant, I. (1998). Kritik der reinen Vernunft. Hrg. v. Jens Timmermann. Hamburg: Meiner.

Kant, I. (1999). Critique of Pure Reason / transl. by N.O. Lossky; with variants of the transl. in Russian and European languages. Moscow: Nauka. [In Russian].

Kant, I. (2000). Critique of pure reason / transl. from German and notes by Igor Burkovsky. Kyiv: Universe. [In Ukrainian].

Kant, I. (2006). Critique of Pure Reason: in 2 parts. P. 1 / Ed. B. Buschling, N. Motroshilova. Works in German and Russian. Volume 2, part 1. Moscow: Nauka. [In Russian].

Kant, I. (2007). Critique of Pure Reason. Translated, edited, and with an Introduction by Marcus Weigelt. Based on the translation by Max Müller. Penguin Books.

Kant, I. (2007a). Critique of Pure Reason / transl. by N. Kemp Smith. Revised Second Edition. Palgrave Macmillan.

Kant, I. (2013). Krytyka czystego rozumu / przekład: M. Żelazny. Dzieła zebrane. Tom 2. Toruń: Wydawnictwo Naukowe Uniwersytetu Mikołaja Kopernika. 
Kant, I. (2018). Prolegomena to every future metaphysics that that will be able to come forward as science. 2nd ed. / transl. from German by V. Terletsky. Editor-in-Chief V. Kebuladze. Kharkiv.: Folio. [In Ukrainian].

Kovalchuk, G.I. (2001). Book apparatus. Encyclopedia of Modern Ukraine. Volume 1. [w. p.]: Coordination Bureau of ESU NAS of Ukraine. [In Ukrainian].

Minakov, M.A. (2007). History of the concept of experience: Monograph. Kyiv: Ed. PARAPAN. [In Ukrainian].

McLaughlin, P. (1999). [Review of:] Immanuel Kant, Kritik der reinen Vernunft, edited by J. Timmermann, Felix Meiner Verlag, Hamburg, 1998... Erkenntnis, 51, 357-363.

Rosiak, M. (2011). Dialektyka Hegla. Krytyczny komentarz do głównych tekstów metafizycznych. Kraków: Universitas.

Savchin, V. (2008). Anatoliy Onyshko: "If it is worth doing at all .... Vsesvit, (3-4), 206-211. [In Ukrainian].

Shpett, G. (1904). Immanuel Kant. Critique of Pure Reason / transl. by N.M. Sokolov et al. Voprosy filosofii i psikhologii, 74(4), 550-564. [In Russian].

Taxidou, O. (1991). Stage sculpture: Beckett's body / transl. from English by I. Burkovsky. Vsesvit, 10 (754), 104-108.

Terletsky, V. (2000). Kant in the Ukrainian reading. Knyzhnyk-review, 6 (6), 6. [In Ukrainian].

Terletsky, V. (2005). I. Kant's "Prolegomena”: Transcendental Philosophy in statu nascendi. Kant, I. Prolegomena to every future metaphysics that that will be able to come forward as science / transl. from German, introductory article, comments and notes by V. Terletsky. Scientific editor V.I. Kebuladze. Kyiv: PPS-2002, I-LIV.

Terletsky, V. (2006). Kant in Ukrainian: problems and dilemmas. Ukrayinskyi humanitarnyi ohlyad, (12), 135-153. [In Ukrainian].

Terletsky, V. (2015). Ukrainian view on Kant's anthropology. Filosofska dumka, (2), 67-71. [In Ukrainian].

Terletsky, V. (2018). I. Kant's "Prolegomena": Transcendental Philosophy in statu nascendi. In: Kant, I. Prolegomena to every future metaphysics that that will be able to come forward as science. 2nd ed. Translated from German by Vitaly Terletsky. Editorin-Chief V. Kebuladze. Kharkiv: Folio, III-LXX. [In Ukrainian].

Thorpe, L. (2015). The Kant Dictionary. Bloomsbury philosophy dictionaries.

Weigelt, M. (2007). Introduction. Kant, I. Critique of Pure Reason / transl., edited, and with an Introduction by M. Weigelt (pp. XV-LXIX). Penguin Books.

Willaschek, M., Stolzenberg, J., Mohr, G., \& Bacin, S. [Herausgegeber] (2015). Kant-Lexikon. Bd. 1-3. Berlin: De Gruyter.

Zhuchkov, V.A. (1999). From the publisher. Kant, I. Critique of Pure Reason / transl. by N.O. Lossky; with variants of the transl. in Russian and European languages. Moscow: Nauka, 5-11. [In Russian].

Żelazny, M. (2013). Od tłumacza. Kant, I. Krytyka czystego rozumu / przekład: M. Żelazny. Dzieła zebrane. Tom 2. Toruń: Wydawnictwo Naukowe Uniwersytetu Mikołaja Kopernika, 7-28. 


\section{Ihor Burkovskyi. Apology of the Ukrainian Kantiana: a critique of the nihilistic critique of the first Ukrainian-language "Critique"}

The article deals with the review of the Ukrainian translation of "Critique of Pure Reason" (CPR) from the previous issue of the magazine. The publication of I. Ivashchenko and V. Terletsky tries to prove the thesis of unsatisfactory quality of translation - the article proves the failure of this attempt. It is shown that most of the reviewers' remarks are untenable, and, most importantly, the presented material is highly insufficient to prove their thesis. Unsatisfactory text quality means not just the presence of errors in it, but their high frequency. For an expansive text, a demonstration on a representative sample is required (its approximate format is offered) - there is nothing similar in the review. Some of its remarks are terminological, which may mean high-frequency errors, due to the repetition of certain terms, but in fact the valid points of those remarks are to point out a few omissions and variability in the translation of some less important terms. The review states that the terms should be translated "everywhere in the same way", while the use of a synonym causes, and inevitably, "the destruction of the structure of the argument". The first assertion is applicable with limitations, especially in the case of CPR, which is not characterized by terminological scrupulousness, and the second is a great exaggeration. The reviewers did not demonstrate any such grave consequences of the synonymy of the terms. In fact, the review proves only that there are flaws in the translation - but this is natural, they are in any translation, in the Ukrainian one they were additionally caused by the unfavorable conditions in which it was made. To neutralize these errors, it is to develop and distribute a list of amendments to the text.

Key words: translation, terminology, provability, counterargumentation, Immanuel Kant, "Critique of Pure Reason", philosophical education.

Ігор Бурковський, кандидат філологічних наук, магістр філософії, старший науковий співробітник відділу загального мовознавства, Інститут мовознавства ім. 0.0. Потебні НАН України

Email: 2201@i.ua

orcid: https://orcid.org/0000-0002-6481-1115

Ihor Burkovskyi (Burkowski), PhD in Philology, Master of Philosophy, Senior Research Fellow at the Department of General Linguistics, 0.0. Potebnya Institute of Linguistics, NAS of Ukraine

Email: 2201@i.ua

orcid: https://orcid.org/0000-0002-6481-1115 